\title{
IMMIGRATION AND THE \\ MACROECONOMY: SOME NEW EMPIRICAL EVIDENCE
}

Francesco tunanetto an o rjan Robstad.

Documentos de Trabajo. N. 1716

\section{BANCODE ESPAÑA}

Eurosistema

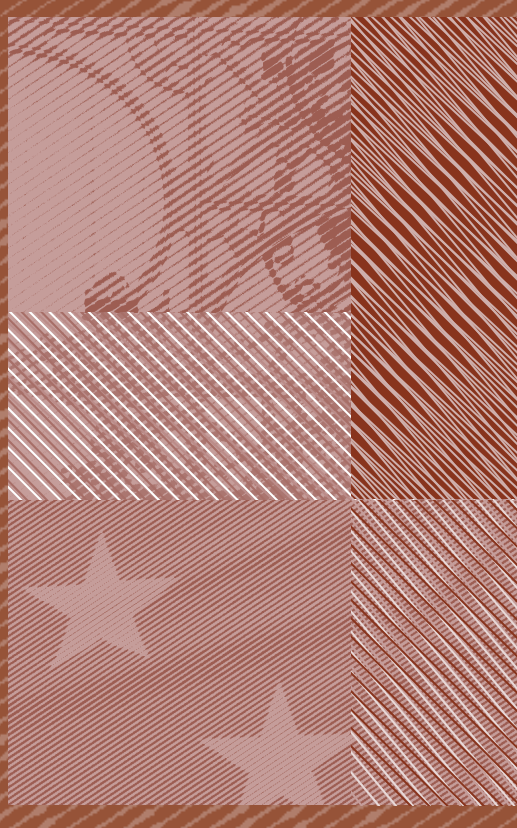


IMMIGRATION AND THE MACROECONOMY: SOME NEW

EMPIRICAL EVIDENCE 
IMMIGRATION AND THE MACROECONOMY: SOME NEW

EMPIRICAL EVIDENCE ${ }^{*}$

\author{
Francesco Furlanetto ${ }^{(*)}$ \\ NORGES BANK AND BANCO DE ESPAÑA
}

Ørjan Robstad ${ }^{(* *)}$

NORGES BANK

$\left(^{*}\right)$ This working paper should not be reported as representing the views of Norges Bank or the Banco de España. The views expressed are those of the authors and do not necessarily reflect those of Norges Bank or the Banco de España. For their useful comments, we thank Faroog Akram, Henrique Basso, Hilde Biørnland, Sultanija Bojceva Terzijan, Fabio Canova, Jim Costain, Efrem Castelnuovo, Guilherme de Almeida Bandeira, Stefano Eusepi, John Fernald, Alessandro Galesi, Jordi Galí, Kåre Hagelund, Veronica Harrington, Torbjørn Hægeland, Juan Francisco Jimeno, Antoine Lepetit, Einar Nordbø, Miles Parker, Chris McDonald, Andreas Økland, Eva Ortega, Gert Peersman, Omar Rachedi, Juan Rubio Ramírez, Aysegul Sahin, Emiliano Santoro, James Stock, Carlos Thomas, Juuso Vanhala, Thjis Van Rens, Fredrik Wulfsberg, Francesco Zanetti, participants at various seminars and conferences, and all members of Tilbudssidegruppen at Norges Bank and the Directorate General Economics, Statistics and Research at the Banco de España.

$\left.{ }^{\star \star}\right)$ Corresponding author. Norges Bank, P.O. Box 1179 Sentrum, 0107 Oslo, Norway, currently on leave at the Banco de España, whose hospitality is gratefully acknowledged. E-mail: francesco.furlanetto@norgesbank.no.

$\left.{ }^{(\star \star}\right)$ Norges Bank, Bankplassen 2, P.O. Box 1179 Sentrum, 0107 Oslo, Norway. E-mail: orjan.robstad@norges-bank.no. 
The Working Paper Series seeks to disseminate original research in economics and finance. All papers have been anonymously refereed. By publishing these papers, the Banco de España aims to contribute to economic analysis and, in particular, to knowledge of the Spanish economy and its international environment.

The opinions and analyses in the Working Paper Series are the responsibility of the authors and, therefore, do not necessarily coincide with those of the Banco de España or the Eurosystem.

The Banco de España disseminates its main reports and most of its publications via the Internet at the following website: http://www.bde.es.

Reproduction for educational and non-commercial purposes is permitted provided that the source is acknowledged.

(c) BANCO DE ESPAÑA, Madrid, 2017

ISSN: 1579-8666 (on line) 


\section{Abstract}

We propose a new VAR identification scheme that enables us to disentangle immigration shocks from other macroeconomic shocks. Identification is achieved by imposing sign restrictions on Norwegian data over the period 1990Q1 - 2014Q2. The availability of a quarterly series for net immigration is crucial to achieving identification. Notably, immigration is an endogenous variable in the model and can respond to the state of the economy. We find that domestic labour supply shocks and immigration shocks are well identified and are the dominant drivers of immigration dynamics. An exogenous immigration shock lowers unemployment (even among native workers), has a small positive effect on prices and on public finances, no impact on house prices and household credit, and a negative effect on productivity.

Keywords: labour supply shocks, immigration shocks, job-related immigration, identification, VAR.

JEL classification: C11, C32, E32. 


\section{Resumen}

Proponemos un nuevo esquema de identificación VAR que nos permite separar perturbaciones migratorias de otras perturbaciones macroeconómicas. La identificación se logra imponiendo restricciones de signo a datos noruegos para el período I TR 1990-II TR 2014. La disponibilidad de series trimestrales para la inmigración neta es crucial para lograr identificación. En particular, la inmigración es una variable endógena en el modelo y puede responder al estado de la economía. Encontramos que las perturbaciones de oferta de mano de obra doméstica y las perturbaciones migratorias están bien identificadas y son los principales impulsores de la dinámica migratoria. Una perturbación exógena de inmigración reduce el desempleo (incluso entre los trabajadores nativos), tiene un pequeño efecto positivo sobre los precios y sobre las finanzas públicas, no afecta a los precios de la vivienda ni al crédito de los hogares y tiene un efecto negativo sobre la productividad.

Palabras clave: perturbaciones de oferta de trabajo, perturbaciones de inmigración, inmigración laboral, identificación, VAR.

Códigos JEL: C11, C32, E32. 


\section{Introduction}

During the past decades immigration flows have increased significantly in most advanced economies. This is certainly the case for Norway, where the population share of immigrants has increased from approximately 3.5 percent in 1990 to over 12 percent in 2014 . While a large literature has studied in detail the effects of immigration flows on employment and wages using mostly disaggregate data, the impact of immigration on standard macroeconomic variables has not been investigated systematically. This paper aims at filling this gap. We conduct our analysis using Norwegian data as Norway is one of the few countries for which a quarterly net immigration series is available from the early 1990s.

Our goal is to include a net immigration variable into a Vector Autoregression (VAR) model, which is the most widely used empirical model for macroeconomic analysis. Notably, immigration is a fully endogenous variable in our set-up and responds to exogenous immigration shocks but also to a series of macroeconomic disturbances driving the business cycle. Following the seminal contributions of Canova and De Nicoló (2002), Faust (1998), Fry and Pagan (2011), Peersman (2005) and Uhlig (2005), our identification strategy is based on imposing a limited number of sign restrictions on macroeconomic variables to disentangle immigration shocks from other sources of business cycle fluctuations. Our main contribution is to investigate the impact of immigration shocks on selected variables that we leave unrestricted in the estimation, such as unemployment, a measure of the state of public finances, house prices, household credit growth, prices and exchange rates and a measure of productivity. Furthermore, we are able to quantify the relative importance of immigration shocks for macroeconomic dynamics and evaluate the strength of the endogenous response of immigration to the other shocks identified in our system.

As already anticipated, our analysis is feasible since Norway is one of the few countries for which a quarterly net immigration series is available from the early 1990s. This series, plotted in Figure 1, is provided by Statistics Norway and has been used by Gjelsvik, Nymoen and Sparrman (2015) to analyze the impact of immigration on the wage formation system. We include in our analysis only the net flow of workers immigrating to Norway from EU/EFTA countries, North America, Australia, New Zealand and Eastern Europe 
in percent of the population aged 15-74. We exclude from our analysis immigrants from Africa, Asia (including Turkey) and South and Central America since our identification assumptions are most likely violated for immigrants that do not enter rapidly into the labor force (as is the case for asylum seekers, for example). The case of Norway is particularly interesting as immigration was a marginal phenomenon in the 1990s (cf. Figure 2), whereas it became the dominant driver of population growth in the aftermath of the EU enlargement to include Eastern European countries (cf. Grangård and Nordbø, 2012). In addition, Norway is an interesting laboratory to disentangle the immigration shock from two other labor market shocks. The first is a domestic labor supply shock that turns out to be particularly important, as participation is cyclical and volatile in Norway. The second is a wage bargaining shock that may have a structural interpretation in Norway given the centralized nature of the wage negotiation system (cf. Aukrust, 1977), in which the wage norm is determined in the sector exposed to international competition (wage leader) and is then used to guide wage increases in the other sectors of the economy (wage followers).

We disentangle the three labor market shocks (wage bargaining, domestic labor supply and immigration shocks) from business cycle shocks by assuming that they imply a negative co-movement between output and real wages. Our assumption finds theoretical support in recent macroeconomic models (cf. Galí, Smets and Wouters, 2011, and Foroni, Furlanetto and Lepetit, 2015) and empirical support in studies investigating the impact of immigration in Norway (cf. Bratsberg and Raaum, 2012, and Bratsberg, Raaum, Røed and Schøne, 2014). To identify the wage bargaining shock we use data on the participation rate and assume that a wage bargaining shock that lowers the real wage also reduces the participation rate. To separate domestic labor supply shocks from immigration shocks we rely on a restriction on the ratio of immigrants over participants that is naturally procyclical in response to an expansionary immigration shock and countercyclical in response to an expansionary domestic labor supply shock. In addition to the three shocks originating in the labor market, our baseline set-up includes a business cycle shock that moves output and real wages in the same direction and that is supposed to capture shocks that 
do not originate in the labor market (such as demand shocks, oil shocks and productivity shocks).

We estimate several versions of our baseline model introducing one alternative unrestricted variable in each experiment. This strategy enables us to investigate the macroeconomic effects of immigration shocks on variables such as unemployment, public finances, house prices, household credit, prices, exchange rates and productivity. The analysis of the drivers of immigration and the effects of immigration shocks on macroeconomic variables constitute the key contributions of this paper.

In terms of impulse responses, several results emerge from our analysis. First, an exogenous increase in immigration lowers the unemployment rate and even the unemployment rate for native workers. Second, a positive immigration shock increases public spending in the medium run, but the response of fiscal revenues follows the same path and the net effect on public finances turns out to be even positive in the short run and neutral in the long run. Third, the immigration shock has no effect on house prices, which are mainly driven by business cycle shocks, but also by domestic labor supply shocks that generate a negative conditional correlation between house prices and immigration. Thus, if anything, immigration has had a mitigating effect on the housing boom that Norway has experienced in our sample period. The same result is confirmed when we consider household credit growth. Fourth, an expansionary immigration shock has no effect on domestic prices but results in an increase in the CPI in the medium run through an exchange rate depreciation. Fifth, labor productivity falls in response to an immigration shock.

In terms of variance decompositions, our main result is that immigration shocks are non-negligible (although not major) drivers of the Norwegian business cycle, explaining on average around 15-20 percent of output fluctuations. Immigration responds little to the state of the business cycle in Norway, whereas it reacts more to factors that are specific to the Norwegian labor market: when participation by native workers is low (i.e. in response to a negative domestic labor supply shock), immigration increases significantly. 
The literature on immigration in the context of macroeconomic models is surprisingly limited, perhaps due to the absence of reliable quarterly series for net immigration over a sufficiently long period for many countries. Mandelman and Zlate (2012) propose a dynamic stochastic general equilibrium (DSGE) model with immigration focusing on the role of remittances for business cycles in Mexico. Earlier contributions include Canova and Ravn (1998), who study the macroeconomic impact of a flow of unskilled migrants in the neo-classical growth model, and Bentolila, Dolado and Jimeno (2008), who show how immigration flattens the slope of the New Keynesian Phillips curve for prices in Spain. In the VAR literature, Kiguchi and Mountford (2013) provide an analysis on US annual data using the penalty function approach in which a shock to the working population (that could be due to immigration but also to domestic factors) leads to a temporary reduction in GDP and consumption per capita. D'Albis, Boubtane and Coulibaly (2015) use monthly data for France over the sample period 1994-2008 in a VAR identified with a recursive scheme. They find that immigration responds significantly to France's macroeconomic outlook and at the same time immigration itself increases GDP per capita, particularly in the case of family immigration. The closest papers to our analysis are two recent and interesting analyses on New Zealand data. In the first, McDonald (2013) studies the effect of an immigration shock on house prices in a VAR identified with a recursive scheme. He shows that an immigration shock has a strong positive effect on house prices and construction activity, thus boosting aggregate demand even more than aggregate supply. The second paper, Armstrong and McDonald (2016), extends the previous set-up to include a second immigration shock associated with fluctuations in Australian unemployment. They find that higher net immigration due to a higher Australian unemployment rate leads to a higher unemployment rate in New Zealand, whereas higher net immigration for other reasons reduces unemployment in New Zealand. Our contribution to this previous literature is the identification of an immigration shock that is distinct from other shocks using a minimum amount of sign restrictions. 
While we could find only a few DSGE and VAR studies on the macroeconomic effects of immigration, the literature using more disaggregate data is extremely rich (for a survey cf. Kerr and Kerr, 2011, and Hagelund, Nordbø and Wulfsberg, 2011). Selected issues of interest are the assimilation of immigrants into the host-country labor market in terms of wages and employment, the identification of displacement effects on native workers in terms of wages and employment (cf. Friedberg and Hunt, 1995, and Borjas, 2003, among many others), the impact of immigration on public finances (cf. Borjas, 1999, Preston, 2014, Storesletten, 2000, among others), on house prices (cf. Saiz, 2003, Ottaviano and Peri, 2006, Nordbø, 2013, and Sá, 2014, among others), on prices and the composition of demand (cf. Lach, 2007, Cortes, 2008, and Frattini, 2008, among others) and on productivity (cf. Peri, 2012). While we impose as an identification assumption that an immigration boom has a dampening effect on wages (in keeping with previous empirical evidence for Norway), our set-up can shed light on all the macroeconomic issues listed above in the context of an aggregate time-series approach that is complementary to analysis based on more disaggregate data and with a microeconomic focus. Notably, the main advantage of a macroeconomic approach based on sign restrictions over alternative approaches is the ability to disentangle the exogenous and the endogenous component of immigration.

The paper is structured as follows. Section 2 presents the VAR model and describes the identification strategy. In Section 3 we propose results for our baseline case with unemployment introduced as an unrestricted variable in the system. Section 4 presents several extensions to discuss the effects of immigration shocks on public finances, house prices, household credit, prices, exchange rates and productivity. Finally, Section 5 concludes. 


\section{The VAR model and the identification strategy}

We start from the standard reduced-form VAR representation:

$$
y_{t}=C_{B}+\sum_{i=1}^{P} B_{i} y_{t-i}+u_{t},
$$

where $y_{t}$ is an $N \times 1$ vector containing our $N$ endogenous variables, $C_{B}$ is an $N \times 1$ vector of constants, $B_{i}$ for $i=1, \ldots, P$ are $N \times N$ parameter matrices, with $P$ the maximum number of lags we include in the model ( 5 in our specific case), and $u_{t}$ is the $N \times 1$ one step ahead prediction error with $u_{t} \sim N(0, \Sigma)$, where $\Sigma$ is the $N \times N$ variance-covariance matrix.

Given the large number of parameters to be estimated, we use Bayesian methods. Moreover, the model is specified and estimated with variables in levels, as the Bayesian approach can be applied regardless of the presence of non-stationarity (cf. Sims, Stock, and Watson, 1990, for more details on this point). We specify diffuse priors so that the information in the likelihood is dominant. These priors lead to a Normal-Wishart posterior with mean and variance parameters corresponding to the OLS estimates. To obtain identification via sign restrictions, we follow the procedure described in RubioRamirez, Waggoner and Zha (2010). Additional details about the estimation procedure are provided in Appendix A1.

In order to map the economically meaningful structural shocks from the reduced form estimated shocks, we need to impose restrictions on the estimated variance-covariance matrix. In detail, the prediction error $u_{t}$ can be written as a linear combination of structural innovations $\epsilon_{t}$

$$
u_{t}=A \epsilon_{t}
$$

with $\epsilon_{t} \sim N\left(0, I_{N}\right)$, where $I_{N}$ is an $(N \times N)$ identity matrix and where $A$ is a non-singular parameter matrix. The variance-covariance matrix has thus the following structure $\Sigma=$ $A A^{\prime}$. Our goal is to identify $A$ from the symmetric matrix $\Sigma$, and to do that we need some restrictions. Those restrictions are imposed only on impact, following the recommendation of Canova and Paustian (2011), and are sufficient to disentangle four identified shocks (one 
general business cycle shock and three shocks originating in the labor markets) and a fifth shock that captures the residual dynamics in the system.

In our baseline estimation exercise we include five series: GDP for mainland Norway (thus excluding petroleum and ocean transport activities, as is standard in all macroeconomic analysis for Norway), the series for real wages (defined as nominal wage costs per hour deflated by core CPI), the participation rate from the labor force survey, the immigration rate series (including only the stock of immigrants living in Norway from EU/EFTA countries, North America, Australia, New Zealand and Eastern Europe in percent of the population aged 15-74) derived from the net immigration series provided by Statistics Norway and the unemployment rate from the Norwegian Labor and Welfare Administration (NAV). A detailed description of the dataset is presented in Appendix A2. The sample period is 1990 Q1-2014 Q2.

The impact restrictions imposed in our baseline model are summarized in Table 1.

Table 1: Impact restrictions in the baseline model

\begin{tabular}{|c|c|c|c|c|}
\hline & Business Cycle & Wage Barg. & Dom. Labor Supply & Immigration \\
\hline \hline GDP & + & + & + & + \\
\hline Real Wages & + & - & - & - \\
\hline Participation Rate & + & - & + & + \\
\hline Immigrants/Participants & NA & NA & - & + \\
\hline Unemployment Rate & NA & NA & NA & NA \\
\hline
\end{tabular}

The business cycle shock is defined as a shock that moves output, real wages and the participation rate in the same direction. Its interpretation as a generic business cycle shock relies on the fact that both real wages and the participation rate are pro-cyclical in Norway. It is supposed to capture shocks originating in the oil sector (cf. Bjørnland and Thorsrud, 2016), different kinds of demand shocks (such as government spending shocks and monetary policy shocks) and to some extent also technology shocks (although the response of participation to technology shocks is model-dependent, cf. Christiano, Eichenbaum and Trabandt, 2015).

The three remaining shocks originate in labor markets: a wage bargaining shock and two labor supply shocks, one domestic and one driven by exogenous immigration flows. 
The wage bargaining shock is defined as a shock that generates countercyclical dynamics in real wages and in the participation rate. These restrictions find strong theoretical support in a New Keynesian model with search and matching frictions and endogenous labor force participation, as discussed in Foroni, Furlanetto and Lepetit (2015), but also in the model of unemployment proposed by Galí, Smets and Wouters (2011). Notice that, as already mentioned in the Introduction, Norway is the ideal laboratory to study wage bargaining shocks given its highly centralized system of wage negotiation. While this shock does not play an important role in our analysis, it allows us to introduce the participation rate into the system in a meaningful way and it guarantees that the remaining labor market shocks are not contaminated by shocks originating in the wage negotiation process (that may also capture fluctuations in unemployment benefits and in matching efficiency).

Our definition of an immigration shock is rather simple and intuitive: it is a shock that generates a positive co-movement between output and participation and a negative co-movement between output and real wages. ${ }^{1}$

The first assumption implies that ideally we would like to concentrate only on immigrants that enter rapidly into the labor force, irrespective of their geographical origin. However, as the quarterly immigration series from Statistics Norway is only available by country-groups, we cannot isolate job-related immigration. Nevertheless, by focusing on immigration from western countries we capture a substantial share of the recent immigration boom, which is mostly job-related (cf. Figure 1). Notably, additional annual data from Statistics Norway confirm that work is the major motivation for immigration from the countries included in our analysis, whereas this is not the case for the countries excluded from our analysis, as it can be seen in Table 2. Moreover, data from 2014 confirm that the immigrants included in our series have on average a higher employment and unemployment rate than natives, thus suggesting a higher participation rate. In contrast, immigrants from non-western countries exhibit an employment rate substantially lower than natives and access the country mainly via family reunification or as asylum seekers.

\footnotetext{
${ }^{1}$ Note that we use the mainland real GDP series (and not the per-capita series) in the estimation. It would not be obvious to assume that a positive immigration shock increases GDP per capita.
} 
Therefore, those immigrants may enter the labor force only with a long delay, in contrast with our identification assumption for immigration shocks.

Our second identification assumption is that an exogenous increase in immigration has a negative effect on real wages on impact. This assumption follows from a standard labor supply-demand framework in which immigrants are expected to lower the relative wages of natives and previous immigrants for whom they are close substitutes (although the wages of complementary workers may even increase). While those wage-mitigating effects of immigration are usually found to be small in the literature (cf. Friedberg and

Table 2: Immigration statistics Norway 1990-2015

\begin{tabular}{ccccc} 
& All immigrants & Included & Excluded & Natives \\
\hline Work main reason & 34 & 54 & 6 & NA \\
Refugees & 19 & 8 & 34 & NA \\
Family reunification & 36 & 30 & 46 & NA \\
Other reasons (e.g education) & 11 & 8 & 14 & NA \\
Employment rate (2014) & 63.4 & 73.0 & 54.5 & 69.4 \\
Unemployment rate (2014) & 7.1 & 5.8 & 9.1 & 1.5 \\
Share of population (1990) & 3.6 & 1.9 & 1.6 & 96.4 \\
Share of population (2014) & 12.4 & 6.0 & 6.4 & 87.6 \\
\hline \hline
\end{tabular}

Note: Included are immigrants from EU/EFTA countries, North America, Australia, New Zealand and Eastern Europe, while excluded are immigrants from Africa, Asia (including Turkey) and South and Central America. All numbers in this table are in percent

Hunt, 1995), more recent studies based on national labor markets for workers of different skills and work experience tend to find larger negative effects (cf. Borjas, 2003). ${ }^{2}$ In addition, and most importantly for our purposes, two recent influential studies on Norwegian data also support our identification assumption as a sensible starting point to identify immigration shocks. Bratsberg and Raaum (2012) investigate the evolution of wages in the Norwegian construction sector over the period 1998-2005, a period of rising immigrant employment in the sector. They exploit the requirements of certifications and

\footnotetext{
${ }^{2} \mathrm{~A}$ continuing controversy on the magnitude of these wage dispacement effects is evident in the literature (cf. Card, 2005, and Borjas, 2003). Ottaviano and Peri (2012) build on the Borjas framework and extend it to estimate the elasticity of substitution across different groups of workers. They find a small and significant degree of imperfect substitutability between native and immigrant workers and conclude that the long-run effect on wages is small. Here, it is important to emphasize that our identification assumption relates to the short-run effect on wages and is imposed on average wages rather on native wages.
} 
authorizations of skills according to national standards as a source of exogenous variation across different segments of the construction sector. In fact, those licensing requirements made it difficult for immigrants to enter some segments (like electrical installation and plumbing activities) but not others (like carpenter and painting firms). They find that a $10 \%$ increase in immigration leads to a decline in wages for native workers by $0.6 \%$. Bratsberg, Raaum, Røed and Schøne (2014) extend the previous analysis over a longer sample period (1993-2006) and consider other sectors by using the national skill cell approach (cf. Borjas, 2003) on data drawn from Norwegian administrative registers. They confirm negative wage effects with a larger impact on previous immigrant wages than on native wages and with native wages responding more to inflows of immigrants from Nordic countries than from developing countries, thus reflecting a higher degree of substitutability between native and Nordic workers.

We complete the characterization of an immigration shock by including the immigration rate as a separate variable into the system and imposing a restriction on the ratio of immigrants over participants to disentangle immigration shocks from domestic labor supply shocks. Somewhat intuitively, we assume that on impact (and only on impact) an expansionary domestic labor supply shock lowers the ratio of immigrants over participants, whereas an exogenous increase in immigration increases the same ratio. Note that we are just assuming that the relative impact of an immigration shock is larger over the pool of immigrants than over the pool of participants, thus ruling out extreme shifts in the participation pattern of native citizens. Along the same lines, the response of immigration to an expansionary domestic labor supply shock is allowed to be positive or negative. If positive, however, we impose that the immigration response has to be lower than the participation response.

Finally, we include a fifth shock to match the number of shocks with the number of observables. This is a residual shock that does not satisfy the restrictions imposed on the other four identified shocks. Although it is supposed to capture only the residual dynamics in the system, the shock has an economic interpretation: it is a shock that 
moves output and participation in different directions and output and wages in the same direction. ${ }^{3}$ In this way, the system is fully identified.

\section{Results}

In this section we present results for our estimated baseline VAR model and for a series of alternative specifications.

\subsection{Baseline Model}

We plot in Figure 3 the impulse responses to an immigration shock in our estimated baseline VAR model. The responses of all variables are expressed in percent, except for the unemployment rate that is expressed in percentage points. An expansionary immigration shock has persistent effects on GDP, real wages, the participation rate and the immigration rate, despite only restricting the impact response for all these variables. While the expansionary effect on GDP is sizeable, the maximum effect is achieved well before the peak in the immigration response. Notably, unemployment declines on impact and more so after few quarters. This partly reflects the mechanical response due to an increase in participation, although this mechanical effect is very small. The size of the response is remarkable and may highlight some complementarities between immigrants and natives. Such an expansionary effect on unemployment is not necessarily surprising if we consider that many immigrants (in particular from Eastern Europe) move to Norway with a job offer. Notably, a decline in unemployment in response to an increase in immigration is consistent with previous estimates for the US based on a production function approach (cf. Peri, 2012).

\footnotetext{
${ }^{3}$ These dynamics are generated by technology shocks in the models by Foroni, Furlanetto and Lepetit (2015) and Campolmi and Gnocchi (2015). However, participation is pro-cyclical (conditional on technology shock) in the model by Christiano, Eichenbaum and Trabandt (2015). Given these constrasting results, we refrain from a structural interpretation of the residual shock. Nonetheless, its presence in the system is useful, as it allows us to leave the fifth variable in the system completely unrestricted, arguably an important benefit of our specification.
} 
Let us now try to interpret these dynamics. The hump-shaped response in the immigration rate may be explained by the combination of three factors. First, it may be due to registration delays. Registration is in fact mandatory only for contracts longer than six months and it is possible that many workers start working in Norway on short-term contracts (thus contributing to GDP) and only register once they obtain a longer contract. Second, the peak after ten quarters may reflect family reunifications. As we have seen in Table 2, while work is the main reason why immigrants included in our sample come to Norway, the importance of family reunifications is far from negligible. It is reasonable to think that a substantial share of these additional immigrants will not enter the labor force, thus explaining why the immigration rate's response is more persistent than the participation rate's response. Finally, the hump-shaped response of immigration may also be explained by network effects, i.e. the fact that immigrants from the same country tend to follow each other. The establishment of large communities of immigrants from Sweden, Poland and Lithuania may also be related to these network effects, in addition of course to the role played by geographical proximity. In addition, the fact that the GDP response peaks only after 4 quarters, well before the peak in immigration, may reflect composition effects leading to a decline in productivity in the economy that may reconcile a substantial and persistent decline in unemployment with a short-lived effect on GDP. We will explore this conjecture further in the next section.

In Figure 4 we plot impulse responses to an expansionary domestic labor supply shock. The dynamics generated by this shock are similar to those generated by an immigration shock (although substantially more persistent). The important difference is that the immigration rate declines (rather than increasing) in response to a positive shock over a long horizon. The different response of the immigration rate highlights how our identification scheme is successful at disentangling these two labor market shocks.

The immigration rate responds significantly to the domestic labor supply shock but is substantially less responsive to the other three shocks (cf. Figure 5). It increases following a reduction in the bargaining power of workers and an expansionary residual shock, whereas it declines in response to a business cycle shock. However, all these effects 
are not statistically significant. ${ }^{4}$ Notably, immigration exhibits a hump-shaped response to all five identified shocks, thus extending our previous discussion on delayed registration, family reunifications and network effects also of other shocks.

These results indicate that immigration responds little to the state of the business cycle in Norway (and to shocks in the wage negotiation process) whereas it reacts substantially to domestic labor supply shocks: when participation from natives is low, immigration increases significantly. The muted response of immigration to business cycle shocks is somewhat puzzling, but may reflect the flexibility of the native labor force. In fact, the marginal participants in the native labor force, who are likely to be close substitutes for labor immigrants, increase native participation in response to a positive business cycle shock, thus possibly reducing the demand for immigrant workers. The cyclicality of native participation is enhanced by the fact that schooling is counter-cyclical in Norway.

The importance of labor supply factors for immigration dynamics emerges also from Figure 6 where we plot the variance decomposition across different horizons as derived from our model. The immigration rate is driven mainly by immigration shocks and domestic labor supply shocks. The immigration shock is also a non-negligible (although not major) driver of GDP and real wages, whereas it is even the main driver of the unemployment rate. The three labor market shocks grouped together explain an average of $50 \%$ of GDP fluctuations and account for a dominant share of unemployment fluctuations. Such an important role for these shocks is not surprising given the large number of labor market variables used as observables in the estimation. ${ }^{5}$

\footnotetext{
${ }^{4}$ In the Online Appendix we present all the remaining impulse responses. The wage bargaining shock is set apart from the domestic labor supply shock on the basis of the participation response, which is negative on impact and essentially flat afterwards. A decline in the bargaining power of workers lowers unemployment in keeping with the predictions of standard New Keynesian models. In the Online Appendix we also further disentangle the business cycle shock into two components: a productivity shock that moves output and prices in opposite directions and a demand shock that moves output and prices in the same direction. Our main results are confirmed in that extended set-up for which the estimation is more computationally intensive.

${ }^{5}$ An important role for labor supply factors in VAR models estimated on US data has been found by Shapiro and Watson (1988), Chang and Schorfheide (2003) and Foroni, Furlanetto and Lepetit (2015). Those shocks are supposed to capture mainly demographic factors, but alternative interpretations have been discussed recently in the literature (cf. Barnichon and Figura, 2015).
} 
The variance decompositions for output and the labor force participation rate turn out to be rather similar, reflecting the large pro-cyclicality of participation in Norway. In contrast, the different profiles of the variance decompositions for output and unemployment (and the limited role of business cycle shocks for unemployment fluctuations) are perhaps more surprising. Those results are, however, consistent with estimates of Okun's law for Norway indicating that a decline in GDP relative to trend of $1 \%$ results in an increase in unemployment relative to trend of only 0.25 percentage points (cf. Ball, Leigh and Loungani, 2012). While unemployment is less cyclical in Norway than in other countries, our results show that the unemployment response is relatively large (and the output response is relatively limited) conditional on immigration shocks. This may relate to the negative response of labor productivity, which we will discuss in the next section.

\subsection{Alternative specifications}

A decline in unemployment in response to an exogenous increase in immigration seems to be in contrast with important displacement effects on natives. Nevertheless, it is interesting to re-estimate our model using a measure of unemployment for native Norwegians that has been available since 1995-Q1 rather than the total unemployment rate. Notwithstanding the difference in the sample period, we remark in Figure 7 that the decline in unemployment for natives is almost identical to the decline in total unemployment in our baseline model. All in all, we do not find any evidence in favor of displacement effects. In contrast, we find positive spillovers that may suggest a high degree of complementarity between domestic and foreign workers.

We now focus on a few selected results by proposing an extensive sensitivity analysis. For each case we plot in Figure 8 the response of the unemployment rate to a positive immigration shock and the variance decompositions for the unemployment rate and the immigration rate.

In a first experiment, we reconsider the horizon at which we impose the sign restrictions. In our baseline, model we impose restrictions only on impact. This assumption may be more problematic for variables featuring a high degree of stickiness, as may be the 
case for wages. Therefore, we check whether our main results are confirmed in a version of the model where all the restrictions on wages are imposed at horizon four (and only at horizon four). The results emerging from the baseline model are broadly confirmed in this alternative set-up, although the importance of immigration shocks for unemployment fluctuations is somewhat reduced.

In a second experiment, we use a different wage series in the estimation by focusing on wages in the construction sector. We thus impose the less restrictive assumption that only wages in the construction sector decline in response to a positive immigration shock, in keeping with the micro-evidence of Bratsberg and Raaaum (2012). Our results are basically unaffected.

In a third experiment we consider a shorter sample period ending in 2004Q1, just before the EU enlargement to include Eastern European countries. The response of unemployment is more muted in this case and domestic labor supply shocks are the main drivers of unemployment. It is reassuring that immigration shocks are less important in this shorter sample period, as we expect a relevant role for immigration shocks precisely in the early phase of the EU enlargement.

In a final experiment, we exclude immigrants from Eastern Europe from the immigration series. The response of unemployment is unchanged in this case. Nevertheless, we note one important difference from our baseline model. The immigration variable is now driven almost exclusively by immigration shocks or, put differently, the endogenous response of immigration to domestic labor supply shocks is now minor. This hints at the possibility that the endogenous component of immigration may be driven mainly by Eastern European workers that react flexibly to the state of the labor market in Norway.

\section{The impact of immigration on key macroeconomic variables}

In the previous section, we studied the drivers of the immigration rate and the effect of an immigration shock with a special focus on unemployment to discuss potential employment 
displacement effects through the lenses of our empirical model. In this section, we offer a macro-perspective on some topics that have emerged in the more recent literature on immigration and that have so far been analyzed only in the context of microeconomic studies. In particular, we investigate the link between immigration and public finances, house prices, credit to households, prices and exchange rates, and productivity. In each experiment, we include a different unrestricted variable as the last variable in the system at the place of unemployment. The general results emphasized in the previous section are confirmed in all these alternative experiments. Therefore, the goal of the section is to discuss only the responses of the variables that are left unrestricted in the system. The results are shown in Figures 9 and 10, where in each line we present the impulse response of the variable of interest to a positive immigration shock and to a positive domestic labor supply shock together with the variance decomposition for the variable itself.

Immigration and public finances. The burden that immigrants may place on public finances is often one of the popular arguments used to oppose immigration. Social security programs in host countries (and in Norway in particular) are more generous than in immigrants' originating countries. Borjas (1999) discusses the welfare magnet effects that may attract a large pool of immigrants to countries with generous welfare systems. On the other hand, immigrants may also be net contributors to public finances, especially if young and highly educated. Storesletten (2000) finds that a reform of immigration policies alone could resolve the fiscal problems associated with the aging of the baby boom generation. In particular, he investigates feasible policies in the context of a calibrated general equilibrium model with overlapping generations and suggests the admission to the US of 1.6 million 40-44 year-old highly skilled immigrants annually.

We can investigate the impact of an immigration shock on public finances by including a measure of net fiscal revenues (defined as the difference between tax revenues and public spending) as an unrestricted variable in our system. The response of public finances to a positive immigration shock is hardly significant and, if anything, on the positive side on impact (cf. first line on Figure 9). Notice, however, that when we consider a measure of public spending in isolation, an exogenous increase in immigration leads to an 
impact decline in public spending followed by an increase in the medium run with a peak corresponding to the peak in the immigration response (cf. Figure 3). This medium run increase in government spending may capture the impact of family reunifications, while the short run decline may reflect reduced expenses for unemployment benefits in response to the improved state of the labor market discussed in the previous section. Notably, the impulse responses for net fiscal revenues and government spending can be reconciled only with a positive effect on tax revenues in the medium run. Thus, our result confirms previous findings emerging from the microeconomic literature: the net fiscal impact of an exogenous increase in immigration is relatively small (even slightly positive in the short run) but the effects on both public spending and tax revenues are not negligible, possibly in keeping with the effects discussed in Borjas (1999) and Storesletten (2000). Results are different in the case of an increase in immigration driven endogenously by a negative domestic labor supply shock, which generates a negative conditional correlation between immigration and the state of public finances. In this case, however, it is reasonable to think that the worsening in public finances is driven by the decline in participation from natives, and immigration may even mitigate the negative consequences of the shock.

Immigration and house prices. Immigration booms are often associated with housing booms. McDonald (2013) finds that net migration changes imply large positive effects on house prices in a VAR identified with a recursive structure on New Zealand data. Other papers have shown that immigration has a positive impact on average house prices using disaggregate data from metropolitan areas (cf. Saiz, 2003, Ottaviano and Peri, 2006). ${ }^{6}$ Our VAR is the ideal laboratory to analyze the link between immigration and house prices at the aggregate level by introducing house prices as an unrestricted variable in the model.

As we can see in Figure 9, according to our model, immigration shocks have no impact on house prices. Domestic labor supply shocks generate a negative conditional correlation between house prices and immigration but, as in the case of public finance, it is conceivable

\footnotetext{
${ }^{6}$ Notice that recent research has highlighted a negative impact of immigration on house prices within metropolitan areas in the US and in the UK due to the mobility response of the native population (cf. Saiz and Wachter, 2011, and Sá, 2014).
} 
that the surge in immigration may mitigate the decline in house prices in response to a negative domestic labor supply shock. House prices respond strongly to the business cycle shock, and to some extent to domestic labor supply shocks whereas immigration shocks are almost irrelevant for house price dynamics, as it can be seen in the variance decomposition. More generally, we can conclude that immigration does not seem to play a big role in driving the recent housing boom in Norway. One possible explanation relates to the fact that a large share of immigrants is composed of Eastern European workers active in the construction sector. While many of these workers are unlikely to buy a house (at least in the short run), their contribution to the supply of new houses may be substantial.

Immigration and household credit growth. The connection between immigration and household credit has not been discussed in the literature to the best of our knowledge. Given the increasing attention devoted to household credit as an indicator of financial instability (together with house prices), we include it in one of our experiments. Note, however, that the stock of household debt is a largely predetermined variable, mainly representing credit accorded in the past and unresponsive to shocks almost by construction. In light of this observation, we use household credit in first differences as this is a good approximation for the new credit accorded in the period, a variable potentially more responsive to macroeconomic shocks. Nonetheless, we find that immigration shocks have no impact on household credit growth, unlike positive domestic labor supply shocks which have positive and persistent effects. The variable of interest is mainly driven by business cycle shocks and domestic labor supply shocks, whereas the role of immigration shocks and wage bargaining shocks is negligible, thus confirming our previous results for house prices. We conclude that the exogenous component of immigration does not pose clear challenges to financial stability, while the endogenous component of immigration (the one responding to the domestic labor supply factors) is negatively correlated with commonly used indicators of financial instability.

Immigration, prices and the exchange rate. The effect of an immigration shock on prices is not obvious. On the one hand, the wage mitigating effects of the increase in 
labor supply may put downward pressure on marginal costs and thus on prices, depending on the degree of price rigidity. On the other hand, the size (but also the composition) of aggregate demand for consumer goods changes with a larger population. If supply adjusts with a delay, we may expect an increase in prices. Lach (2007) explores the effects of the massive inflow of Russian Jewish immigrants into Israel during the 1990s and finds that prices of goods decreased. He attributes this result to the higher price elasticity and lower search costs of the new immigrants compared to the existing population. Cortes (2008) considers the effects on non-tradable goods and services (unlike Lach, 2007) in the US and finds a negative effect, in particular for low skill-intensive services. Frattini (2008) finds small effects on UK prices: immigration decreases the growth rate of prices for services and non-traded goods, whereas it tends to increase the prices of tradeable goods.

We introduce a measure of CPI prices as an unrestricted variable in our system and we find no effect on the impact of the shock (cf. Figure 10). Nevertheless, CPI prices tend to increase in the medium run. Notably, this effect seems to be driven by a depreciation of the exchange rate, whereas a measure of domestic prices reacts substantially less to an immigration shock. While these effects are relatively small, in keeping with Frattini (2008), we uncover a new channel (the exchange rate channel) that, as far as we know, has not been discussed in the previous literature. Immigration shocks are important drivers of CPI prices in the medium run, whereas the sum of three labor market shocks captures a dominant share of fluctuations in the exchange rate. The effect on the exchange rate is quantitatively important as immigration shocks explain around 35\% of exchange rate fluctuations at long horizons. In light of these results, investigating the link between labor supply and the exchange rate in theoretical models seems to be an interesting avenue for future research. One tentative interpretation is that the exchange rate depreciation may reflect the impact of remittances.

Immigration and productivity. The impact of immigration on productivity has been discussed in Peri (2012), who finds a strong positive association between immigration and total factor productivity (TFP) in US data. The main channel responsible for this result is task specialization. Peri and Sparber (2009) show that in states with large inflows 
of immigrants, natives with lower education tend to specialize in communication-intensive tasks, leaving more manual-intensive tasks to immigrants. The rebalancing produces task specialization based on comparative advantages and results in efficiency gains.

In our last experiment, we introduce labor productivity, measured as output per hour, as an unrestricted variable in our VAR (cf. Figure 10). We find that immigration shocks lower productivity in the medium run, thus confirming one of the conjectures proposed in the previous section to explain the short-lived effects of immigration on GDP. Notably, positive domestic labor supply shocks (associated with a decline in immigration) lead to a large positive effect on productivity. Therefore, both the exogenous and the endogenous component of immigration induce a decline in productivity. In fact, the variance decomposition suggests that the indirect effect (associated with the endogenous component) may be quantitatively more important to explain the possible negative effects of immigration on productivity.

A negative conditional correlation between immigration and productivity is not surprising since the two series are negatively correlated over the sample period. However, this result seems in contrast with the evidence for the US proposed by Peri (2012). To further investigate this issue, we now try to disentangle the different components of labor productivity. As shown under general assumptions by Bosler, Daly, Fernald and Hobijn (2016), labor productivity can be decomposed into TFP, capital intensity and labor quality. We use data on a measure of TFP (that however does not disentangle labor quality) and on capital intensity to isolate the effects of immigration shocks on the different components of labor productivity. In a first experiment, we include our measure of TFP as an unrestricted variable in the VAR. We see from Figure 10 that a positive immigration shock has a significant positive effect on TFP. In contrast, when we include capital intensity, we find a strong negative effect and immigration shocks are the dominant drivers of capital intensity. These more granular results are now consistent with Peri (2012) who also find a positive effect on TFP, possibly driven by task specialization, and a negative (although not statistically significant) effect on capital intensity. The dominant effect of immigration shocks on capital intensity in Norway may capture the fact that immigration shocks 
induce the adoption of less capital intensive and more unskilled efficient technologies. In keeping with this view, Lewis (2011) finds that US manufacturing plants located in areas that experienced faster growth in immigration adopted significantly less machinery per unit of output.

\section{Conclusion}

The economic impact of immigration is usually investigated in studies using detailed disaggregate data. This paper is one of the first attempts to include net immigration into the set of standard macroeconomic variables in a VAR model identified with a minimum set of sign restrictions. Our goal is to disentangle the drivers of immigration and the impact of immigration shocks on several variables that have been studied in the microeconomic literature. While a disaggregate approach can be more informative and detailed in several dimensions, an aggregate approach is needed to study business cycle fluctuations and possibly also to discuss some implications for macroeconomic policies.

We do not find any support for some of the arguments recently used against immigration in terms of native employment displacement effects and burden on public finances. On the contrary we find that an exogenous positive immigration shock in Norway lowers unemployment (even among native workers) and has a small positive effect on public finances in the short run. Moreover, an exogenous increase in immigration has no impact on house prices and household credit growth, a small positive effect on prices in the medium run and a negative effect on productivity. While the fears for employment and the balance of public finances seem misplaced, the negative impact on labor productivity may be worrisome for long-term growth.

We conclude by briefly discussing the implications of our analysis for financial stability and monetary policy. On the one hand, as already mentioned, the exogenous component of immigration does not seem to pose clear challenges to financial stability, while the endogenous component may even have a stabilizing effect. On the other hand, our VAR framework is not equipped to discuss normative implications for monetary policy. Nevertheless, our analysis may give some indication of the effects of immigration on real 
economic activity and inflation, two key variables for monetary policy. In principle, the positive impact of immigration on the labor force may lead us to the conjecture that immigration has substantial effects on potential output. In practice, however, our analysis seems to downplay those effects. In fact, the negative effect on productivity limits the effects of the exogenous component of immigration on potential output, while the endogenous component of immigration reduces the effects of domestic labor supply shocks on potential output. The effects are larger if we consider the unemployment rate as a better indicator of real economic activity. As long as the natural rate of unemployment is relatively stable in response to exogenous variations in immigration, the fall in unemployment may indicate higher capacity utilization. The combination of a medium-run increase in inflation with higher capacity utilization suggests an expansionary effect of positive immigration shocks on key target variables for monetary policy. 


\section{References}

[1] Armstrong, J., McDonald, C., 2016. Why the drivers of migration matter for the labour market. Reserve Bank of New Zealand Analytical Notes 2016/02.

[2] Aukrust, O., 1977. Inflation in the open economy: A Norwegian model. World Wide Inflation. Theory and Recent Experience, editors L.B. Krause and W.S. Salant, Brookings, Washington DC.

[3] Ball, L.M., Leigh, D., Loungani, P., 2013. Okun's law: fit at fifty. NBER Working Paper Series 18668.

[4] Barnichon, R., Figura, A., 2015. Declining desire to work and downward trends in unemployment and participation. NBER Macroeconomics Annual 2015, forthcoming.

[5] Bentolila, S., Dolado, J.J., Jimeno, J.F., 2008. Does immigration affect the Phillips curve? Some evidence for Spain. European Economic Review 52, 1398-1423.

[6] Bjørnland, H., Thorsrud, L.A., 2016. Boom or gloom? Examining the Dutch disease in two-speed economies. Economic Journal, forthcoming.

[7] Borjas, G., 1999. Immigration and welfare magnets. Journal of Labor Economics 17, 607-637.

[8] Borjas, G., 2003. The labor demand curve is downward sloping: Reexamining the impact of immigration on the labor market. Quarterly Journal of Economics 118, $1335-1374$.

[9] Bosler, C., Daly, M., Fernald, L., Hobijn, B., 2016. The outlook for US labor-quality growth. Federal Reserve Bank of San Francisco, Working Paper 2016-14.

[10] Bratsberg, B., Raaum, O., 2012. Immigration and wages: evidence from construction. Economic Journal 122, 1177-1205.

[11] Bratsberg, B., Raaum, O., Røed, M., Schøne, P., 2014. Immigration wage effects by origin. Scandinavian Journal of Economics 116, 356-393. 
[12] Campolmi, A., Gnocchi, S., 2016. Labor market participation, unemployment and monetary policy. Journal of Monetary Economics, forthcoming.

[13] Canova, F., Ravn, M.O., 1998. Crossing the Rio Grande: Migrations and the welfare state. CEPR Working Paper 2040.

[14] Canova. F., De Nicoló, G., 2002. Monetary disturbances matter for business cycle fluctuations in the G7. Journal of Monetary Economics 49, 1131-1159.

[15] Canova. F., Paustian, M., 2011. Business cycle measurement with some theory. Journal of Monetary Economics 58, 345-361.

[16] Card, D., 2005. Is the new immigration really so bad? Economic Journal 115, 300323.

[17] Chang, Y., Schorfheide, F., 2003. Labor-supply shifts and economic fluctuations. Journal of Monetary Economics 50, 1751-1768.

[18] Christiano, L., Eichenbaum, M., Trabandt, M., 2015. Understanding the Great Recession. American Economic Journal: Macroeconomics 7, 110-167.

[19] Cortes, P., 2008. The effect of low-skilled immigration on US prices: evidence from CPI data. Journal of Political Economy 116, 381-422.

[20] D'Albis, H., Boubtane, E., Coulibaly, D., 2015. Immigration policy and macroeconomic performance in France. Etudes et Documents 5, CERDI.

[21] Dustmann, C., Frattini, T., 2014. The fiscal effects of immigration to the UK. Economic Journal 124, 593-643.

[22] Faust, J., 1998. The robustness of identified VAR conclusions about money. CarnegieRochester Conference Series on Public Policy 49, 207-244.

[23] Friedberg, R.M., Hunt, J., 1995. The impact of immigrants on host countries wages, employment and growth. Journal of Economic Perspectives 9, 23-44. 
[24] Fry, R., Pagan A., 2011. Sign restrictions in Structural Vector Autoregressions. A critical review. Journal of Economic Literature 49, 938-960.

[25] Foroni, C., Furlanetto, F., Lepetit, A., 2015. Labor supply factors and economic fluctuations. Norges Bank Working Paper 7/2015.

[26] Frattini, T., 2008. Immigration and prices in the UK. Manuscript.

[27] Galí, J., Smets, F., Wouters, R., 2011. Unemployment in an estimated New Keynesian model. NBER Macroeconomics Annual 2011, University of Chicago Press, 329-360.

[28] Gjelsvik, M.L., Nymoen, R., Sparrman, V., 2015. Have inflation targeting and EU labour immigration changed the system of wage formation in Norway? Manuscript.

[29] Grangård, H., and Nordbø, E., 2012. High immigration to Norway: who comes and why do they come? Norges Bank Staff Memo 25/2012.

[30] Hagelund, K., Nordbø, E., Wulfsberg, F., 2011. The effects of immigration. Norges Bank Staff memo 12/2011.

[31] Kadiyala, R., Karlsson, S., 1997. Numerical methods for estimation and inference in Bayesian VAR models. Journal of Applied Econometrics 12, 99-132.

[32] Kerr, S.P., Kerr, W., 2011. Economic impacts of immigration: a survey. NBER working paper 16736 .

[33] Kiguchi, T., Mountford, A., 2013. The macroeconomics of immigration. MPRA paper 45517.

[34] Lach, S., 2007. Immigration and prices. Journal of Political Economy 115, 548-587.

[35] Lewis, E., 2011. Immigration, skill mix, and capital skill complementarity. Quarterly Journal of Economics 126, 1029-1069.

[36] Mandelman, F.S., Zlate, A., 2015. Immigration, remittances and business cycles. Journal of Monetary Economics 59, 196-213. 
[37] McDonald, C., 2013. Migration and the housing market. Reserve Bank of New Zealand Analytical Notes 2013/10.

[38] Nordbø, E., 2013. Immigration and house prices in Norway. Norges Bank Staff Memo $8 / 2013$.

[39] Ottaviano, G., Peri, G., 2012. Rethinking the effect of immigration on wages. Journal of the European Economic Association 10, 152-197.

[40] Peersman, G., 2005. What caused the early millennium slowdown? Evidence based on Vector Autoregressions. Journal of Applied Econometrics 20, 185-207.

[41] Peri, G., 2012. The effect of immigration on productivity: evidence from U.S. states. Review of Economics and Statistics 94, 348-358.

[42] Peri, G., Sparber, C,., 2009. Task specialization, immigration and wages. American Economic Journal: Applied Economics 1, 135-169.

[43] Preston, I. 2014. The effect of immigration on public finances. Economic Journal 124, 569-592.

[44] Rubio-Ramirez, J.F., D.F. Waggoner, Zha, T., 2010. Structural Vector Autoregressions: Theory and identification algorithms for inference. Review of Economic Studies 77, 665-696.

[45] Sá, F., 2014. Immigration and house prices in the UK. Economic Journal 125, 13931424.

[46] Saiz, A., 2003. Room in the kitchen for the melting pot: Immigration and rental prices. Review of Economics and Statistics 85, 502-521.

[47] Saiz, A., Wachter, S., 2011. Immigration and the neighborhood. American Economic Journal: Economic Policy 3, 169-188.

[48] Shapiro, M., Watson, M., 1988. Sources of business cycle fluctuations. NBER Macroeconomics Annual 1988, Volume 3, 111-156. 
[49] Sims, C., Stock, J., Watson, M., 1990. Inference in linear time series models with some unit roots. Econometrica 58, 113-144.

[50] Storesletten, K., 2000. Sustaining fiscal policy through immigration. Journal of Political Economy 108, 300-323.

[51] Uhlig, H., 2005. What are the effects of monetary policy on output? Results from an agnostic identification procedure. Journal of Monetary Economics 52, 381-419. 


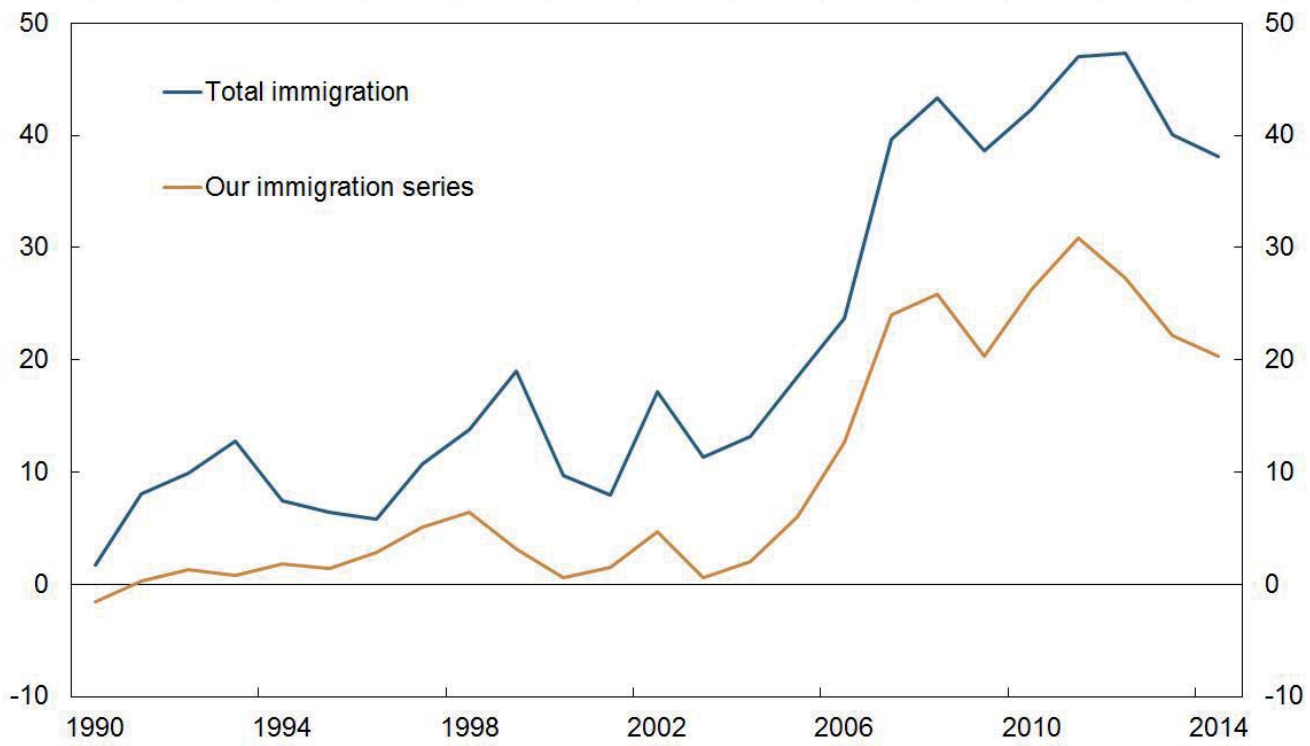

Figure 1: Net immigration to Norway in thousand people. Our immigration series include EU/EFTA countries, North America, Australia, New Zealand and Eastern Europe. Source: Statistics Norway

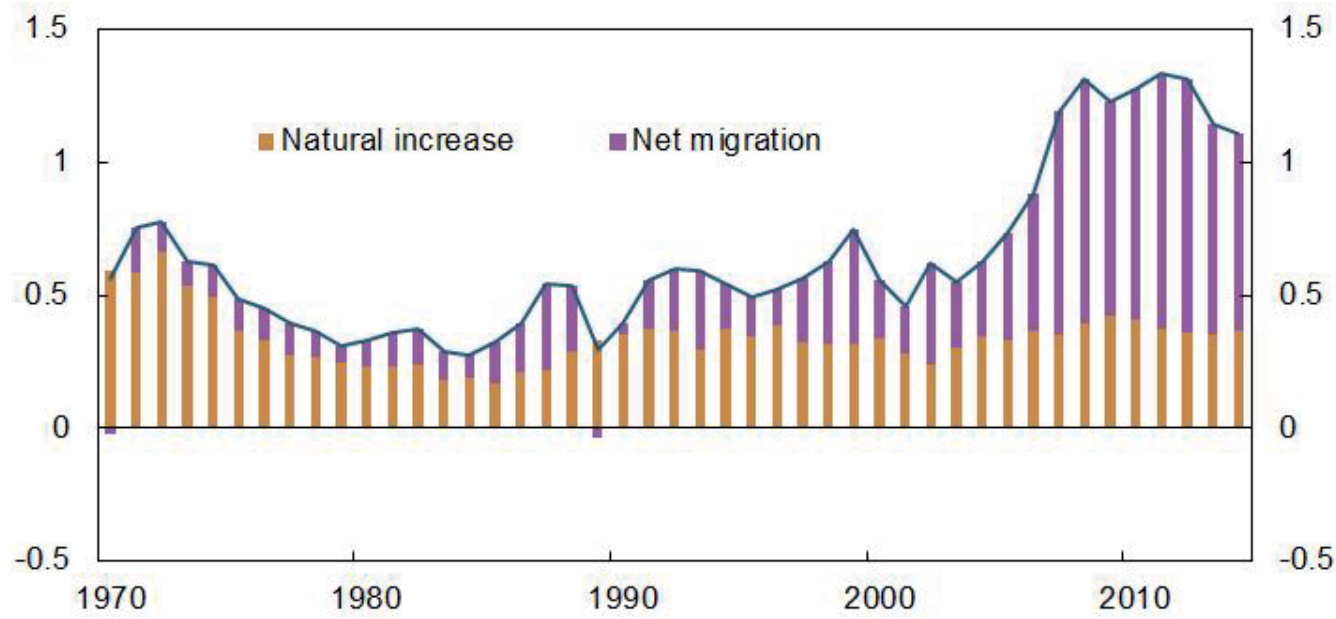

Figure 2: Annual change in population Norway. Percent. Source: Statistics Norway 

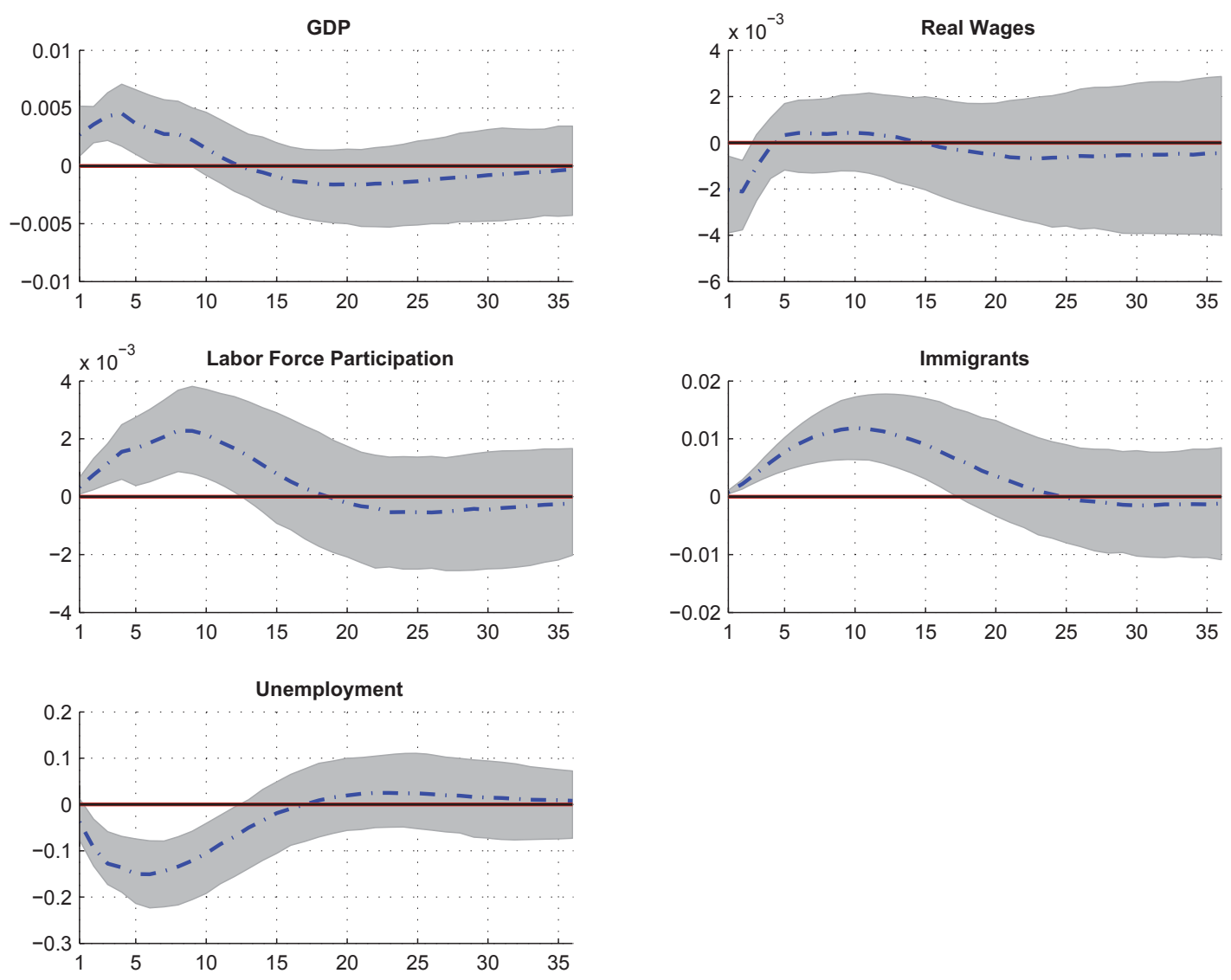

Figure 3: Impulse responses to an one-standard-deviation immigration shock in the baseline model. The dashed-dotted line represent the posterior median at each horizon and the shaded area indicates the 68th posterior probability region of the estimated impulse responses 

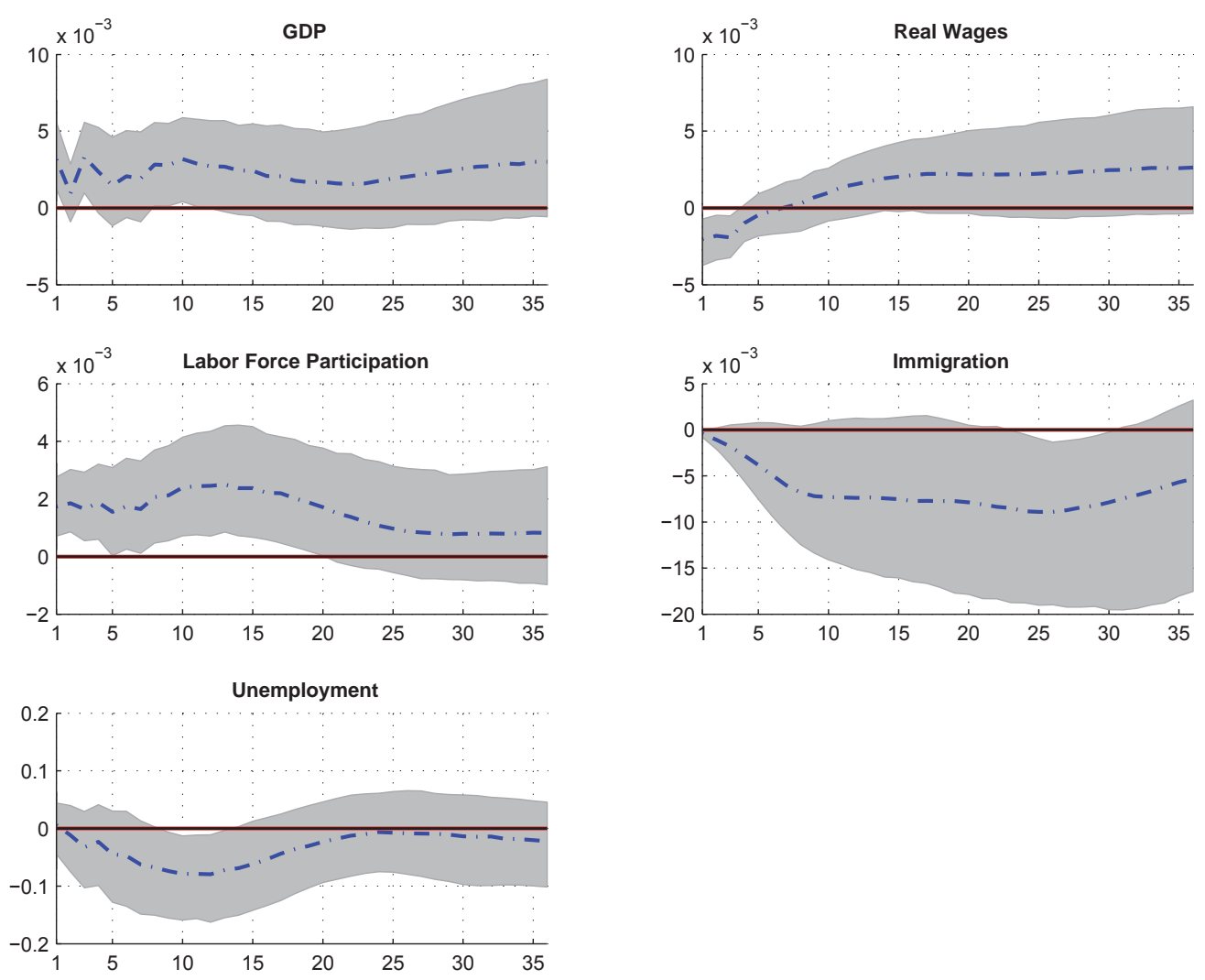

Figure 4: Impulse responses to an one-standard-deviation domestic labor supply shock in the baseline model. The dashed-dotted line represent the posterior median at each horizon and the shaded area indicates the 68th posterior probability region of the estimated impulse responses
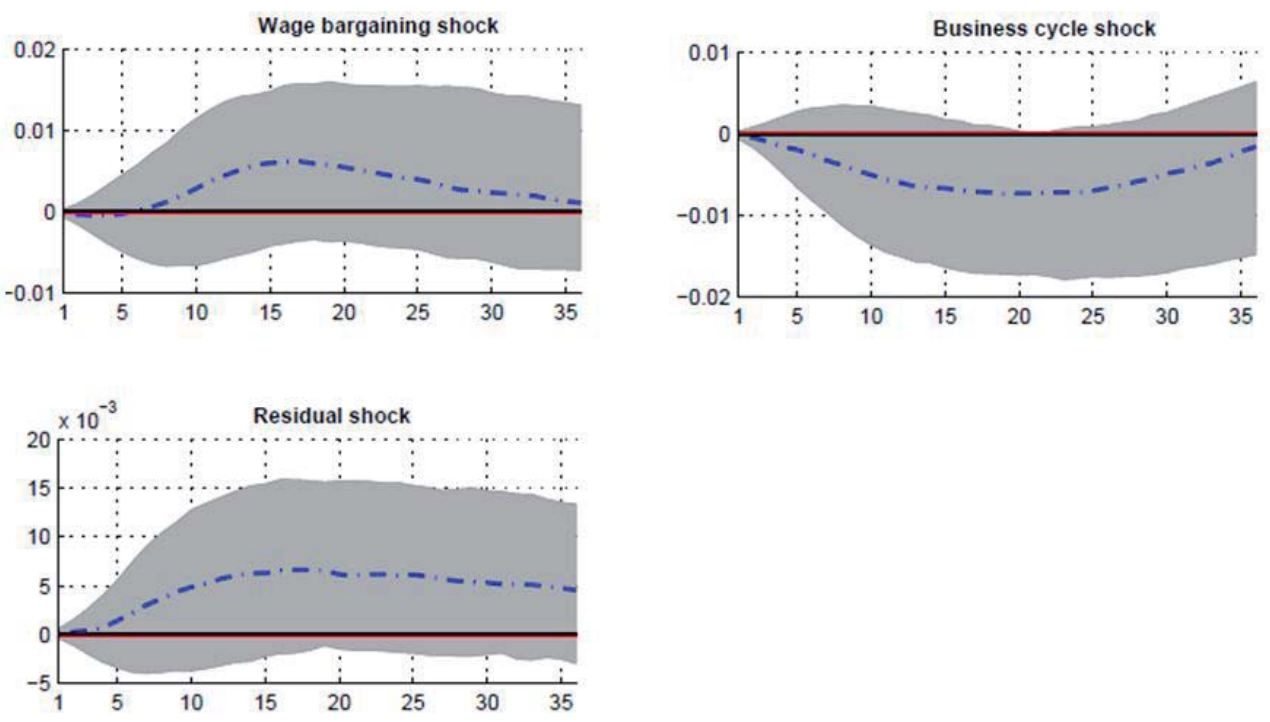

Figure 5: Impulse responses of immigration to a one-standard-deviation wage bargaining, business cycle and residual shock in the baseline model. The dashed-dotted line represent the posterior median at each horizon and the shaded area indicates the 68th posterior probability region of the estimated impulse responses 

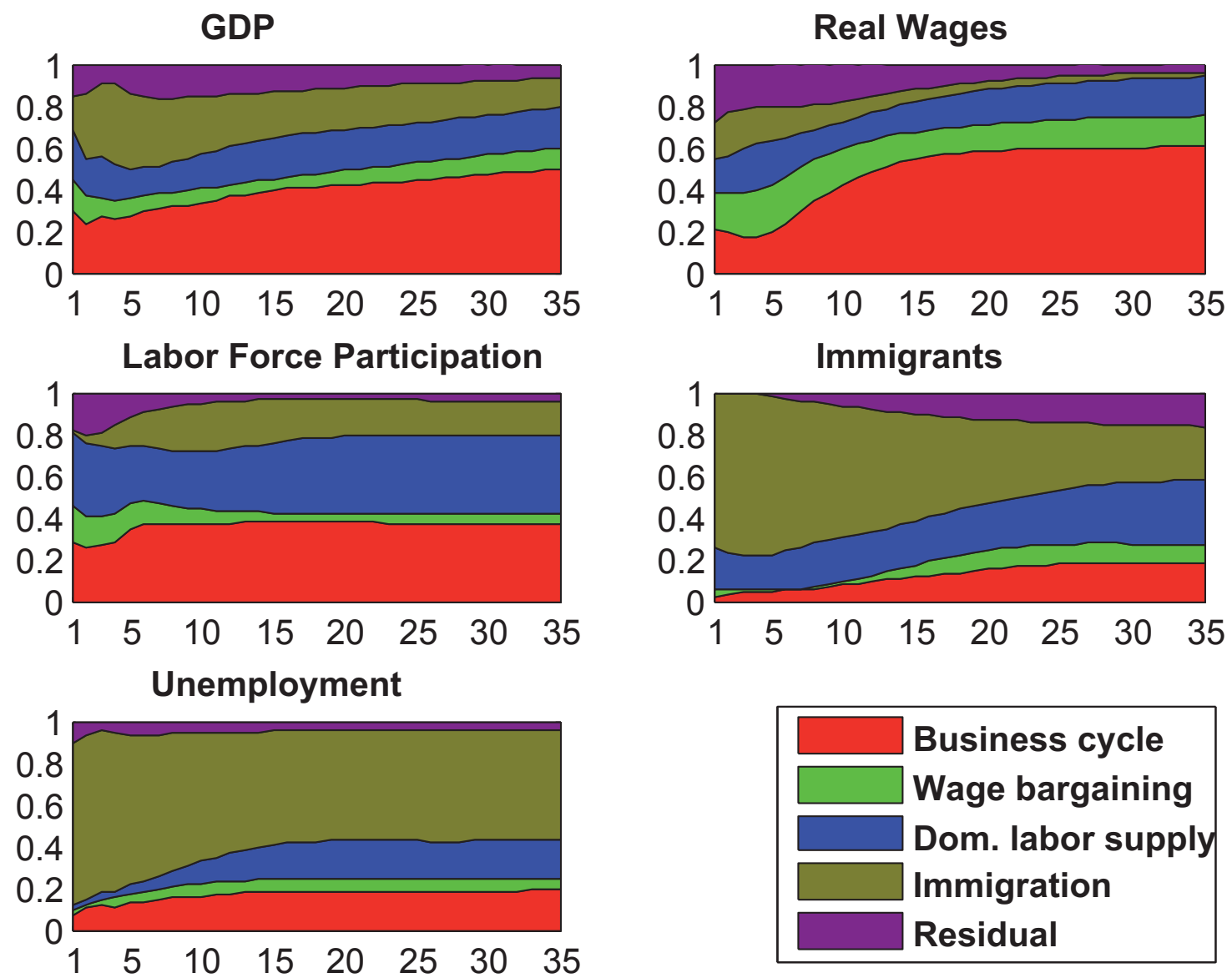

Figure 6: Median forecast error variance decomposition at each horizon in the baseline model
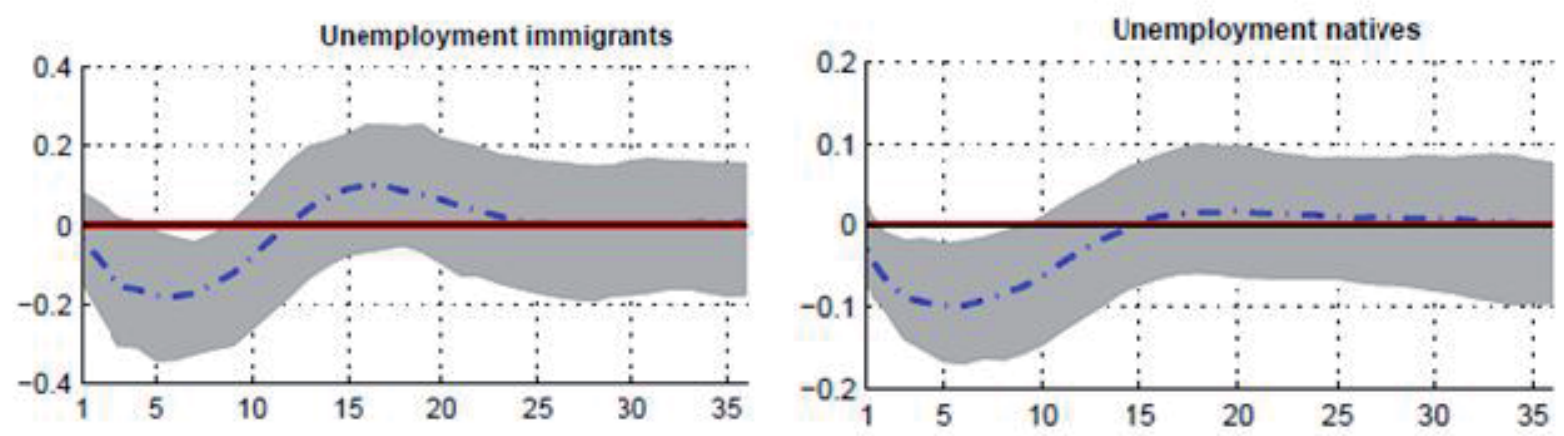

Figure 7: Impulse responses of different unemployment measures to a one-standarddeviation immigration shock where total unemployment in the baseline model is replaced by unemployment among natives and immigrants respectively. The dashed-dotted line represent the posterior median at each horizon and the shaded area indicates the 68th posterior probability region of the estimated impulse responses 
Restricting wages 4 quarters

Wages Construction

Sample 1990 - 2004Q1

Excluding eastern Europe
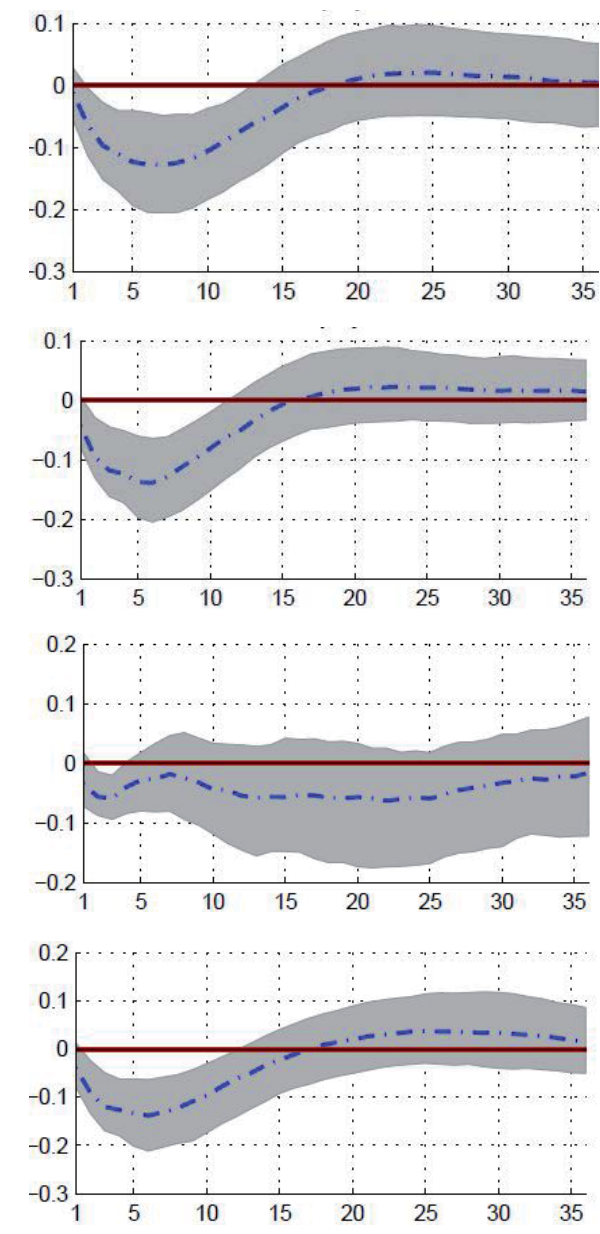

Dom. Labor supply

Immigration
VD unemployment
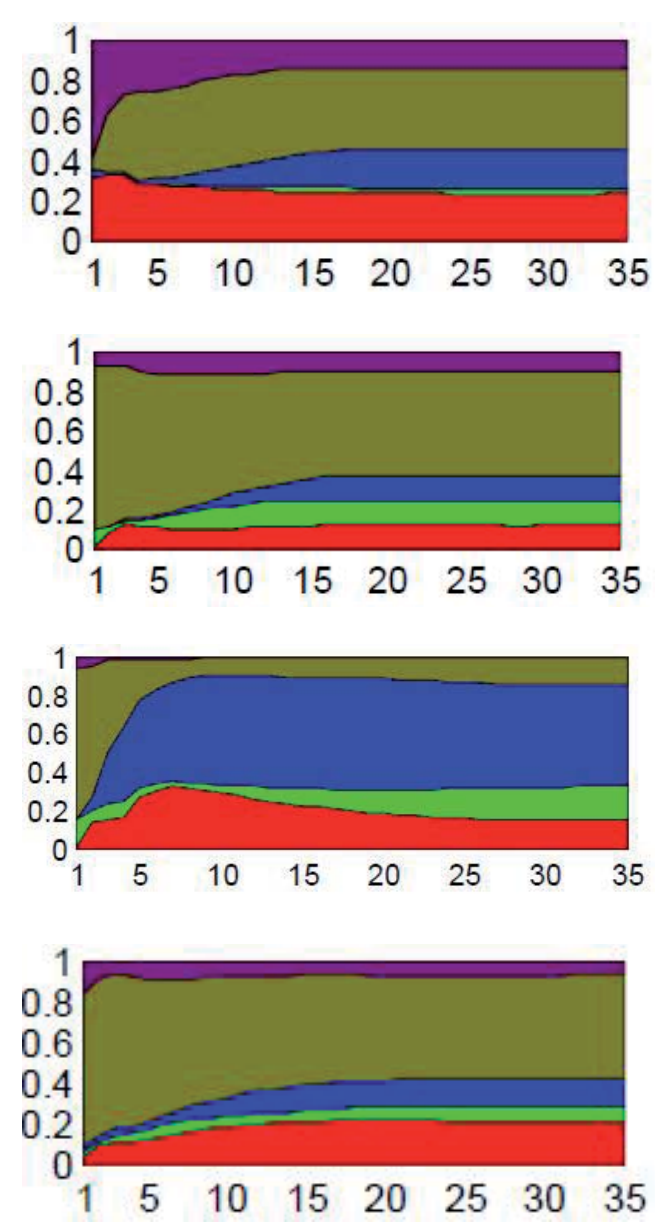

VD immigration
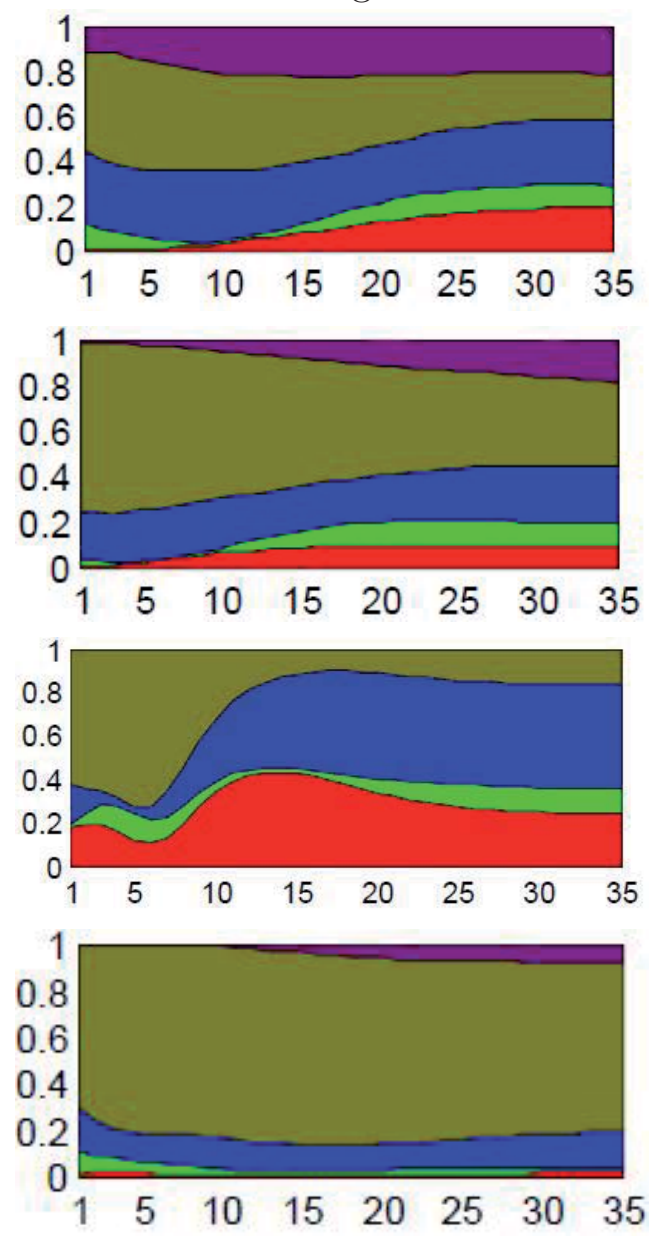

Business cycle

Figure 8: Robustness checks for the impulse response of unemployment to a immigration shock and for the variance decomposition of unemployment and immigration 


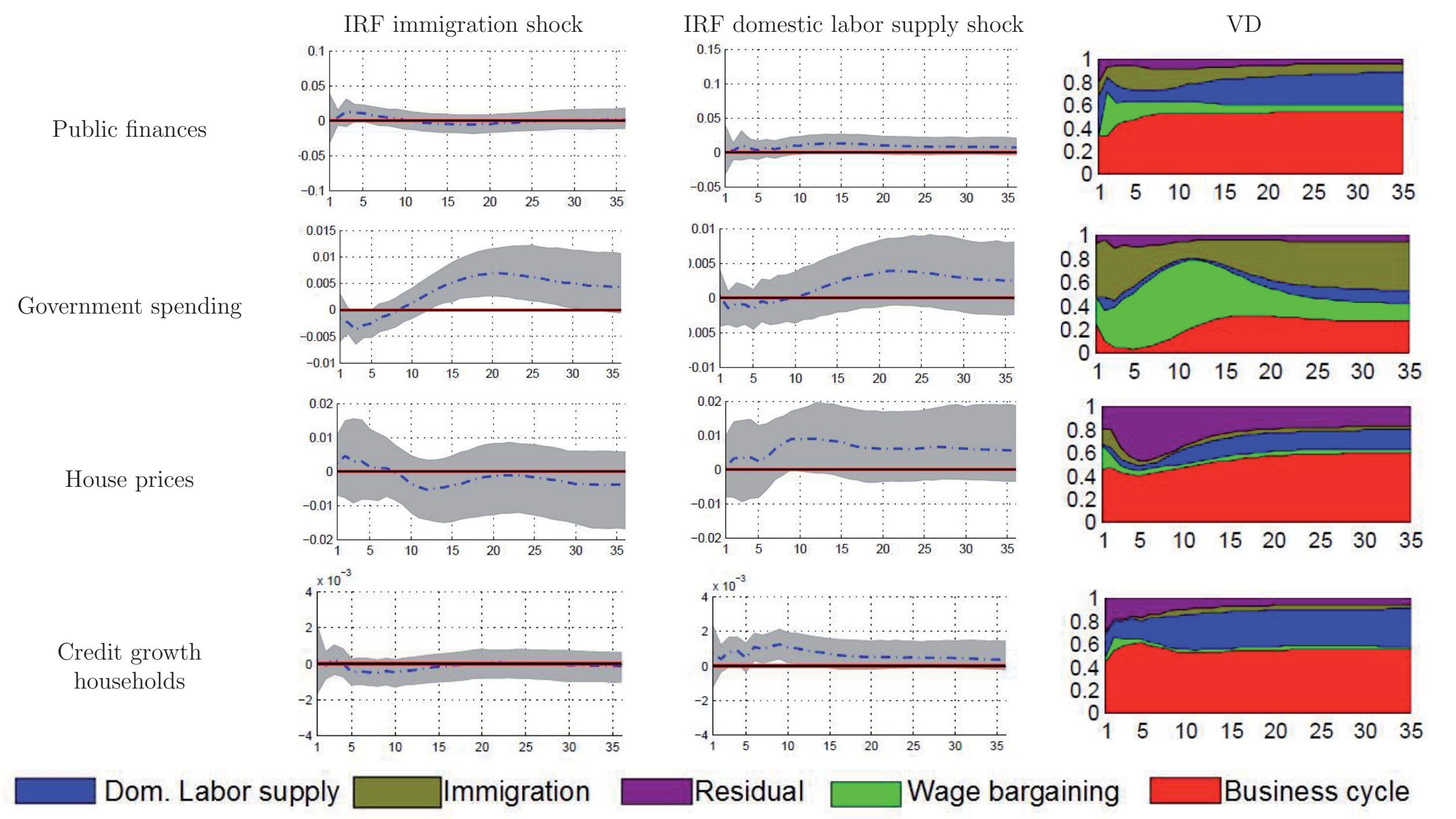

Figure 9: Selected impulse responses and variance decomposition for some variables of interest 


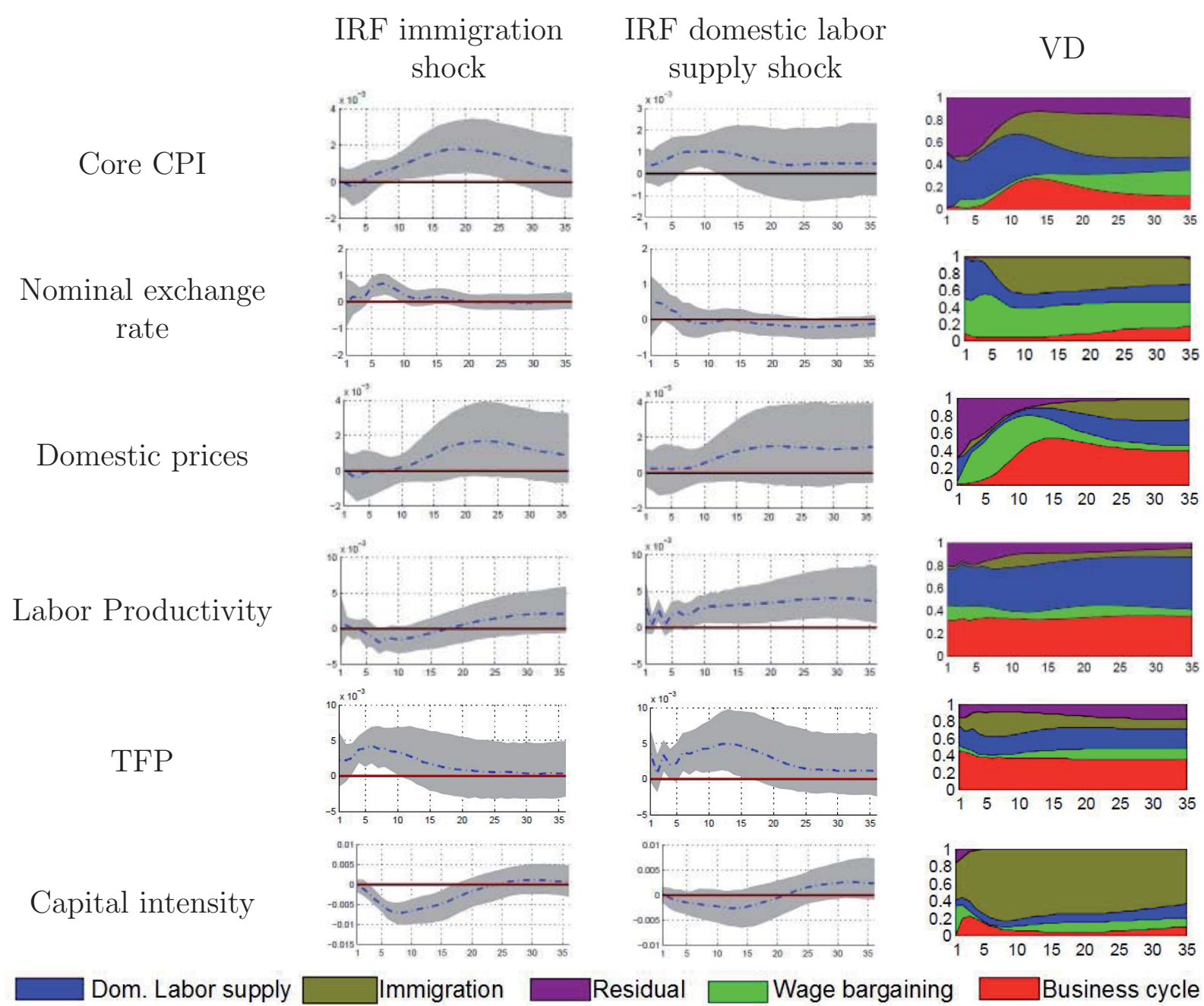

Figure 10: Selected impulse responses and variance decomposition for some variables of interest 


\section{A Appendix}

\section{A.1 Bayesian Estimation of the VAR}

We illustrate in this Appendix the econometric procedure we use for the estimation of the different VAR models presented in the paper.

\section{Estimation procedure}

The VAR model described in (1) can be rewritten in a compact way as:

$$
\mathbf{Y}=\mathbf{X B}+\mathbf{U}
$$

where $\mathbf{Y}=\left[\begin{array}{lll}y_{1} & \ldots & y_{T}\end{array}\right]^{\prime}, \mathbf{B}=\left[\begin{array}{llll}C_{B} & B_{1} & \ldots & B_{p}\end{array}\right]^{\prime}, \mathbf{U}=\left[\begin{array}{ll}u_{1} \ldots u_{T}\end{array}\right]^{\prime}$, and

$$
\mathbf{X}=\left[\begin{array}{cccc}
1 & y_{0}^{\prime} & \ldots & y_{-p}^{\prime} \\
\vdots & \vdots & \vdots & \vdots \\
1 & y_{T-1}^{\prime} & \ldots & y_{T-p}^{\prime}
\end{array}\right]
$$

Finally, for convenience, we rewrite (2) into its vectorized form:

$$
\mathbf{y}=\left(I_{n} \otimes \mathbf{X}\right) \beta+\mathbf{u}
$$

where $\mathbf{y}=\operatorname{vec}(\mathbf{Y}), \beta=\operatorname{vec}(\mathbf{B}), \mathbf{u}=\operatorname{vec}(\mathbf{U})$, and with $\operatorname{vec}()$ denoting columnwise vectorization. The error term $\mathbf{u}$ follows a normal distribution with a zero mean and variance-covariance matrix $\Sigma \otimes I_{T}$.

The likelihood function in $\mathbf{B}$ and $\Sigma$ is defined as:

$$
L(B, \Sigma) \propto|\Sigma|^{-\frac{T}{2}} \exp \left\{-\frac{1}{2}(\beta-\hat{\beta})^{\prime}\left(\Sigma^{-1} \otimes \mathbf{X}^{\prime} \mathbf{X}\right)(\beta-\hat{\beta})\right\} \exp \left\{-\frac{1}{2} \operatorname{tr}\left(\Sigma^{-1} S\right)\right\}
$$

where $S=\left((\mathbf{Y}-\mathbf{X} \hat{\mathbf{B}})^{\prime}(\mathbf{Y}-\mathbf{X} \hat{\mathbf{B}})\right)$ and $\hat{\beta}=\operatorname{vec}(\hat{\mathbf{B}})$ with $\hat{\mathbf{B}}=\left(\mathbf{X}^{\prime} \mathbf{X}\right)^{-1} \mathbf{X}^{\prime} \mathbf{Y}$. We specify diffuse priors so that the information in the likelihood is dominant and these priors lead 
to a Normal-Wishart posterior. In more detail, we use a diffuse prior for $\beta$ and $\Sigma$ that is proportional to $|\Sigma|^{-(n+1) / 2}$. The posterior becomes:

$$
p(B, \Sigma \mid y) \propto|\Sigma|^{-\frac{T+n+1}{2}} \exp \left\{-\frac{1}{2}(\beta-\hat{\beta})^{\prime}\left(\Sigma^{-1} \otimes \mathbf{X}^{\prime} \mathbf{X}\right)(\beta-\hat{\beta})\right\} \exp \left\{-\frac{1}{2} \operatorname{tr}\left(\Sigma^{-1} S\right)\right\},
$$

where $y$ denotes all available data.

The posterior in (4) is the product of a normal distribution for $\beta$ conditional on $\Sigma$ and an inverted Wishart distribution for $\Sigma$ (see, e.g. Kadiyala and Karlsson, 1997 for the proof). We then draw $\beta$ conditional on $\Sigma$ from

$$
\beta \mid \Sigma, y \sim N\left(\hat{\beta}, \Sigma \otimes\left(\mathbf{X}^{\prime} \mathbf{X}\right)^{-1}\right)
$$

and $\Sigma$ from

$$
\Sigma \mid y \sim I W(S, \nu)
$$

where $\nu=(T-n) *(p-1)$ and $N$ representing the normal distribution and $I W$ the inverted Wishart distribution.

\section{Identification procedure}

In order to map the economically meaningful structural shocks from the reduced form estimated shocks, we need to impose restrictions on the variance covariance matrix we estimated.

In detail, the prediction error $u_{t}$ can be written as a linear combination of structural innovations $\epsilon_{t}$

$$
u_{t}=A \epsilon_{t}
$$

with $\epsilon_{t} \sim N\left(0, I_{N}\right)$, where $I_{N}$ is an $(N \times N)$ identity matrix and where $A$ is a non-singular parameter matrix. The variance-covariance matrix has thus the following structure $\Sigma=$ $A A^{\prime}$. Our goal is to identify $A$ from the symmetric matrix $\Sigma$, and to do that we need to impose restrictions.

To obtain identification via sign restrictions, we follow the procedure described in Rubio-Ramirez, Waggoner and Zha (2010). The algorithm has the following steps. First, 
we compute $A$ as the Cholesky decomposition of our estimated variance covariance matrix. We then compute rotations of this matrix, computing first a matrix $Q$ with a $\mathrm{QR}$ decomposition of $X=Q R$, where $X$ is drawn from $X \sim N\left(0, I_{N}\right)$. Then, we generate candidate impulse responses from $A Q$ and $B_{i}$ for $i=1, \ldots, P$ and check if the generated impulse responses satisfy the sign restrictions. If the sign restrictions are satisfied, we store our impulse response, if not we draw a new $X$. We iterate over the same procedure again until we obtain 1000 impulse responses which satisfy our sign restrictions.

\section{A.2 Data sources}

This subsection lists the sources of the data series used in this paper. When the original data series is at a monthly frequency, we take quarterly averages of monthly data. All data series enter the VARs in logs except for unemployment which enters in percent of the workforce.

Immigration rate: Stock of immigrants in the country in percent of population aged 15-74. We include immigrants from EU/EFTA countries, North America, Australia, New Zealand and Eastern Europe. Quarterly gross immigration is collected from Statistics Norway. Net immigration is calculated using interpolated yearly data for emigration. The stock of immigrants is accumulated net immigration. Sources: Statistics Norway and Norges Bank

Real wage: Seasonally adjusted wage costs per hour deflated with the price level (CPIATE). Sources: Statistics Norway and Norges Bank

Participation rate: Seasonally adjusted workforce aged 15-74 in percent of population aged 15-74 from the Labor force survey. Sources: Statistics Norway and Norges Bank

Unemployment rate: Seasonally adjusted registered unemployment rate from the Norwegian Labour and Welfare Administration (NAV). Sources: Statistics Norway and NAV 
GDP mainland Norway: Seasonally adjusted GDP mainland Norway (volumes) from national accounts. Source: Statistics Norway

Prices: Seasonally adjusted consumer price index adjusted for tax changes and excluding energy products (CPI-ATE). Sources: Statistics Norway and Norges Bank

Domestic Prices: Seasonally adjusted consumer price index domestic sources adjusted for tax changes and excluding energy products. Sources: Statistics Norway and Norges Bank

Exchange rate: Trade-weighted nominal exchange rate index (I-44) for 44 trading partners. Sources: Thomson Reuters, Ecowin and Norges Bank

Hours worked: Total hours worked in mainland Norway from national accounts adjusted for population growth. Source: Statistics Norway

Population: Population from 15 to 74. Source: Statistics Norway

House prices: Seasonally adjusted nominal house prices deflated by the CPI-ATE. Sources: Statistics Norway, Eiendomsmeglerforetakenes forening (EFF), Finn.no, Eiendomsverdi and Norges Bank

Household credit: Seasonally adjusted C2 for households chained and break-adjusted deflated by the CPI-ATE and adjusted for population growth. Included in first differences. Sources: Statistics Norway and Norges Bank

Labor Productivity: Seasonally adjusted GDP mainland Norway (volumes) divided by hours worked. Source: Statistics Norway 
TFP and capital intensity: Labor productivity decomposed into total factor productivity and capital intensity using a Cobb-Douglas production function. Data on capital, GDP, hours and labor income share for mainland Norway are used in the calculation. Source: Statistics Norway and Norges Bank

Government spending: Total expenditure from the quarterly central government fiscal account. Seasonally adjusted. Sources: Statistics Norway and Norges Bank

Public finances: Difference between tax income (excluding oil taxes) and government spending from the quarterly central government fiscal account. Seasonally adjusted. Sources: Statistics Norway and Norges Bank 


\title{
BANCO DE ESPAÑA PUBLICATIONS
}

\author{
WORKING PAPERS
}

1601 CHRISTIAN CASTRO, ÁNGEL ESTRADA and JORGE MARTÍNEZ: The countercyclical capital buffer in Spain: an analysis of key guiding indicators.

1602 TRINO-MANUEL ÑíGUEZ and JAVIER PEROTE: Multivariate moments expansion density: application of the dynamic equicorrelation model.

1603 ALBERTO FUERTES and JOSÉ MARÍA SERENA: How firms borrow in international bond markets: securities regulation and market segmentation.

1604 ENRIQUE ALBEROLA, IVÁN KATARYNIUK, ÁNGEL MELGUIZO and RENÉ OROZCO: Fiscal policy and the cycle in Latin America: the role of financing conditions and fiscal rules.

1605 ANA LAMO, ENRIQUE MORAL-BENITO and JAVIER J. PÉREZ: Does slack influence public and private labour market interactions?

1606 FRUCTUOSO BORRALLO, IGNACIO HERNANDO and JAVIER VALLÉS: The effects of US unconventional monetary policies in Latin America.

1607 VINCENZO MERELLA and DANIEL SANTABÁRBARA: Do the rich (really) consume higher-quality goods? Evidence from international trade data.

1608 CARMEN BROTO and MATÍAS LAMAS: Measuring market liquidity in US fixed income markets: a new synthetic indicator.

1609 MANUEL GARCÍA-SANTANA, ENRIQUE MORAL-BENITO, JOSEP PIJOAN-MAS and ROBERTO RAMOS: Growing like Spain: 1995-2007

1610 MIGUEL GARCÍA-POSADA and RAQUEL VEGAS: Las reformas de la Ley Concursal durante la Gran Recesión.

1611 LUNA AZAHARA ROMO GONZÁLEZ: The drivers of European banks' US dollar debt issuance: opportunistic funding in times of crisis?

1612 CELESTINO GIRÓN, MARTA MORANO, ENRIQUE M. QUILIS, DANIEL SANTABÁRBARA and CARLOS TORREGROSA: Modelling interest payments for macroeconomic assessment.

1613 ENRIQUE MORAL-BENITO: Growing by learning: firm-level evidence on the size-productivity nexus.

1614 JAIME MARTÍNEZ-MARTíN: Breaking down world trade elasticities: a panel ECM approach.

1615 ALESSANDRO GALESI and OMAR RACHEDI: Structural transformation, services deepening, and the transmission of monetary policy.

1616 BING XU, ADRIAN VAN RIXTEL and HONGLIN WANG: Do banks extract informational rents through collateral?

1617 MIHÁLY TAMÁS BORSI: Credit contractions and unemployment.

1618 MIHÁLY TAMÁS BORSI: Fiscal multipliers across the credit cycle.

1619 GABRIELE FIORENTINI, ALESSANDRO GALESI and ENRIQUE SENTANA: A spectral EM algorithm for dynamic factor models.

1620 FRANCISCO MARTÍ and JAVIER J. PÉREZ: Spanish public finances through the financial crisis.

1621 ADRIAN VAN RIXTEL, LUNA ROMO GONZÁLEZ and JING YANG: The determinants of long-term debt issuance by European banks: evidence of two crises.

1622 JAVIER ANDRÉS, ÓSCAR ARCE and CARLOS THOMAS: When fiscal consolidation meets private deleveraging.

1623 CARLOS SANZ: The effect of electoral systems on voter turnout: evidence from a natural experiment.

1624 GALO NUÑO and CARLOS THOMAS: Optimal monetary policy with heterogeneous agents.

1625 MARÍA DOLORES GADEA, ANA GÓMEZ-LOSCOS and ANTONIO MONTAÑÉS: Oil price and economic growth: a long story?

1626 PAUL DE GRAUWE and EDDIE GERBA: Stock market cycles and supply side dynamics: two worlds, one vision?

1627 RICARDO GIMENO and EVA ORTEGA: The evolution of inflation expectations in euro area markets.

1628 SUSANA PÁRRAGA RODRÍGUEZ: The dynamic effect of public expenditure shocks in the United States.

1629 SUSANA PÁRRAGA RODRÍGUEZ: The aggregate effects of government incometransfer shocks - EU evidence.

1630 JUAN S. MORA-SANGUINETTI, MARTA MARTÍNEZ-MATUTE and MIGUEL GARCÍA-POSADA: Credit, crisis and contract enforcement: evidence from the Spanish loan market. 
1631 PABLO BURRIEL and ALESSANDRO GALESI: Uncovering the heterogeneous effects of ECB unconventional monetary policies across euro area countries.

1632 MAR DELGADO TÉLLEZ, VÍCTOR D. LLEDÓ and JAVIER J. PÉREZ: On the determinants of fiscal non-compliance: an empirical analysis of Spain's regions.

1633 OMAR RACHEDI: Portfolio rebalancing and asset pricing with heterogeneous inattention.

1634 JUAN DE LUCIO, RAÚL MÍNGUEZ, ASIER MINONDO and FRANCISCO REQUENA: The variation of export prices across and within firms.

1635 JUAN FRANCISCO JIMENO, AITOR LACUESTA, MARTA MARTÍNEZ-MATUTE and ERNESTO VILLANUEVA: Education, labour market experience and cognitive skills: evidence from PIAAC.

1701 JAVIER ANDRÉS, JAVIER J. PÉREZ and JUAN A. ROJAS: Implicit public debt thresholds: an empirical exercise for the case of Spain.

1702 LUIS J. ÁLVAREZ: Business cycle estimation with high-pass and band-pass local polynomial regression.

1703 ENRIQUE MORAL-BENITO, PAUL ALLISON and RICHARD WILLIAMS: Dynamic panel data modelling using maximum likelihood: an alternative to Arellano-Bond.

1704 MIKEL BEDAYO: Creating associations as a substitute for direct bank credit. Evidence from Belgium.

1705 MARÍA DOLORES GADEA-RIVAS, ANA GÓMEZ-LOSCOS and DANILO LEIVA-LEON: The evolution of regional economic interlinkages in Europe.

1706 ESTEBAN GARCÍA-MIRALLES: The crucial role of social welfare criteria for optimal inheritance taxation.

1707 MÓNICA CORREA-LÓPEZ and RAFAEL DOMÉNECH: Service regulations, input prices and export volumes: evidence from a panel of manufacturing firms.

1708 MARÍA DOLORES GADEA, ANA GÓMEZ-LOSCOS and GABRIEL PÉREZ-QUIRÓS: Dissecting US recoveries.

1709 CARLOS SANZ: Direct democracy and government size: evidence from Spain.

1710 HENRIQUE S. BASSO and JAMES COSTAIN: Fiscal delegation in a monetary union: instrument assignment and stabilization properties.

1711 IVÁN KATARYNIUK and JAIME MARTÍNEZ-MARTÍN: TFP growth and commodity prices in emerging economies.

1712 SEBASTIAN GECHERT, CHRISTOPH PAETZ and PALOMA VILLANUEVA: Top-down vs. bottom-up? Reconciling the effects of tax and transfer shocks on output.

1713 KNUT ARE AASTVEIT, FRANCESCO FURLANETTO and FRANCESCA LORIA: Has the Fed responded to house and stock prices? A time-varying analysis.

1714 FÁTIMA HERRANZ GONZÁLEZ and CARMEN MARTÍNEZ-CARRASCAL: The impact of firms' financial position on fixed investment and employment. An analysis for Spain.

1715 SERGIO MAYORDOMO, ANTONIO MORENO, STEVEN ONGENA and MARÍA RODRÍGUEZ-MORENO: "Keeping it personal" or "getting real"? On the drivers and effectiveness of personal versus real loan guarantees.

1716 FRANCESCO FURLANETTO and ØRJAN ROBSTAD: Immigration and the macroeconomy: some new empirical evidence.

BANCODEESPAÑA Eurosistema
Unidad de Servicios Auxiliares

Alcalá, 48 - 28014 Madrid

E-mail: publicaciones@bde.es www.bde.es 